\title{
尿路感染症における混合感染の免疫学的研究
}

\author{
岥阜大学医学部泌尿器科学教室 堀 江 正宣
(主任: 西浦常雄教授)
}

\section{IMMUNOLOGIC STUDIES ON POLYMICROBIAL URINARY INFECTIONS}

\author{
Masanobu Horie \\ Department of Urology, Gifu University School of Medicine
}

(Director: Prof. T. Nishiura)

Significance of polymicrobial infections of the urinary tract was investigated immunologically in 20 patients with long term indwelling catheter.

Relation between bacterial counts in the urine and the serum or urinary antibody levels were studied. Serum and urine-recoated.antibody coated bacteria were detected in relation to the serum or urinary antibody levels and the urinary immunoglobuline levels.

The results obtained were as follows:

1) The serum antibody titers to autologous antigens derived from patients' own feces were below 64. Therefore, the significnat titer of serum antibody was considered 128 or higher.

2) There was a significant correlation between the serum antibody titers to homologous antigens and the bacterial counts in urine.

3) The serum antibody titers tended to rise in two weeks in cases with increasing bacterial counts.

4) There was a significant correlation between the response of serum antibody and the positivity of S-R. ACB of IgG class, and also between the response of urinary antibody and U-R ACB of IgG class. The positive rate of S-R.ACB to IgG and IgA was higher than that to S-IgA and IgM, and the positive rate of U-R.ACB to IgG and S-IgA was higher than the others.

5) There was no significant difference in the urinary immunoglobulin levels of $\operatorname{IgG}$ and $\operatorname{IgA}$ between U-R.ACB positive and negative cases. The levels of urinary immunoglobulin were related to the positivity of U-R.ACB to S-IgA, and IgM of which the positive rate was low.

6) The positive rate of the urinary antibody was $25 \%$ of 12 cases who had had indwelling-catheter for a long time. In all of the urinary antibody positive cases, U-R. ACB to IgG class could be detected. Many organisms isolated from one urinary tract produced their own serum and urinary antibody response and showed positive reaction in R.ACB detection.

要旨: 長期カテーテル留置混合感染症例の20例で, 尿中分離菌の個別菌数, 血清抗体価, 尿中抗体価, Recoated・antibody coated bacteria (R・ACB) の検出, および尿中免疫グロブリソの測定を行ない, 以下の結論を 得た。

1. 患者の自己翼便分離菌の血清抗体俩の測定から，尿路感染症の抗体価陽性限界値を128倍以上々した。

2.一尿路より分離された複数分離菌の血清抗体価は，菌数に比例して高值となる傾向を認めた。

3. 2 週間の間隔を置く 2 時点の抗体洒の変動も菌量の增減に比較的上く同調する傾向を認めた。

4. R・ACB の検討で, IgG の S-R・ACB は血清抗体価と U-R・ACB は尿中抗体洒と相関する傾向を認 めた。抗体分析の結果法，S-R・ACB では IgG，IgA で陽性率が高く，U-R・ACB では IgG, S-IgA で陽性 率が高値を示した。

5. U-R ・ ACB 陽性の尿中免疫グロブリンは S-IgA で高值を示し, 陽性率は低いが IgM でも高值を示し 
たＩgG，IgA では冢中免疫グロブリン量と U R・ACB 陽性間に相関を認めなからた。

6. 厡中抗体価陽性率は12症例中 3 例 (25\%) であつた。尿中抗体価陽性株は全例 IgG の U-R ・ ACB が 陽性であつた。一尿路の分離菌のらち複数の分離菌が, 血清抗体価, 尿中抗体洒, R・ACB 陽性であつた。

\section{緒言}

近年の抗生物質の発展は, 各種感染症の治療に関して は偉大な力を発揮してきた。泌尿器科領域に扮いても, 単純性尿路感染症の治療に関しては汪涪問題がないと言 えよう. 反面, 尿路系に何らかの基礎疾患を伴う複雑性 尿路疾患の治療は, 各種抗生剂が横溢した現状にあつて も難渋することが多い，たと光ば，留置カテーテル症例 に認められる細菌层は, 抗生剂で完全に消退せしめるこ とは不可能に近いばかりでなく，その病的意義すら不明 のままに放置されているのが現状である。このよらな複 雑性尿路感染症は, 腎監腎を進行させ, 腎機能低下の 原因林るのと考兄られるが，一方これらは多種菌株 による混合感染のかたちをとることが多く，また容易に 菌交代を起す。したがつて，まず混合感染に於けるこれ ら個々の菌株が尿路感染に於いて如何なる病的意義を有 しているのかを検討することが必要である.

慢性カテーテル留置症例に括ける尿路感染症は，混合 感染のかたちをとることが多く，UTI 薬効評価基準の 疾患病態群によると第 5 群に属し, 難治性感染症である ことが多い゙．各種泌尿器科疾患で尿路変更術を余儀な くされた患者の予後に影響を与兄るものは, 基礎疾患の 軽重もさることながら, 尿路変更術後にもたらされる慢 性複雑性尿路感染症であって, 看過出来ない問題であ る。

そこで著者は，尿路感染症に打ける混合感染について 検討するに当り, このカテーテル留置混合感染症例を対 象とし，それらの尿から分離される個々の菌株につい て，それぞれの病原的意義を，主として，菌株毎の血清 抗体価，および形式的には分離菌別 $\mathrm{ACB}$ とも言兄る再 生 ACB (Recoated. antibody coated bacteria 以下, R . $\mathrm{ACB}$ )を用いて検討したので報告する.

\section{検討対象および材料}

検討対象は, 混合尿路感染を有している岐阜大学泌尿 器科外来に括ける各種尿路変更患者で, 尿管皮覤瘦 9 例 (男 7 , 女 2 ), 腎瘦 3 例 (女 3 ), 膀胱瘦 3 例 (男 1 , 女 2 ), 尿道留置 5 例（男 5 ）の計20症例とした。基礎 疾患は, 尿管皮膚瘦では膀胱腫汮 7 例, 直腸腫演 2 例, 腎瘦では子宮癌 1 例, 先天性水腎症 2 例であり, 膀胱瘦 では, 尿道癌 1 例, 神経因性膀胱 2 例であって, 尿道留
置症例は，前立腺癌 2 例と前立腺肥大症の 3 例である. 材料は，隔週に来科する患者の尿と血液で，尿は採取当 日に菌株別に定量培盖を行ない, 残りの尿は遠沈および ミリポアフィルターで除菌後, 原尿, 25倍濃縮尿として $-80^{\circ} \mathrm{C} て ゙$ 涷結保存し, 血液も遠心分離後同梯に保存し た。

\section{実験方法}

1. 血清抒よび尿中抗体の検出

a) 菌体抗原の作成

菌体抗原作成法には種々の方法があるが，著者は Kunin $^{2)}$ の方法に準じて作成した。すなわち，尿中分離 菌を HI 寒天培地 (栄研) で分離し, TSB (Trypticase Soy Broth，BBL）て増殖させ，生食にて8,000 rpm 20分 間遠心に上り 3 回洗浄し, 抢上そ $1 \times 10^{9} / \mathrm{ml}$ の浮遊液に して，その $10 \mathrm{ml}$ を 2 時間惹沸後，3,000 rpm 30 分間遠 心した上清を antigen として使用した（図1）.

\section{図 1 Method}

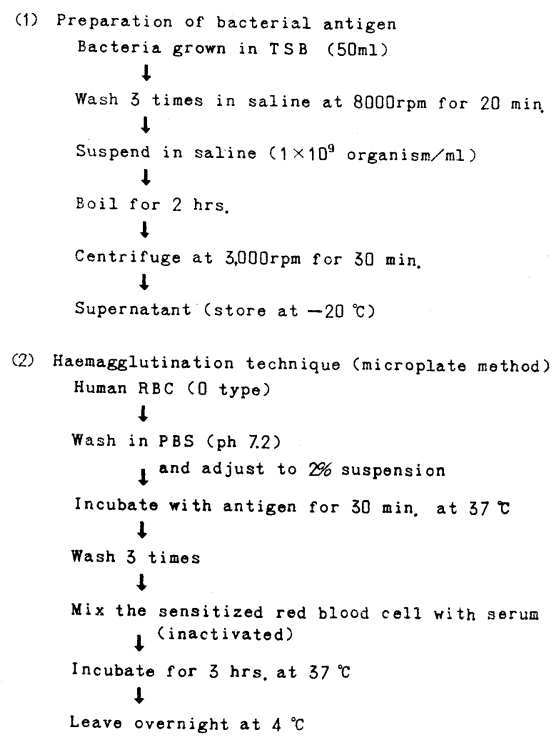

b ) 感作赤血球の作成

O型健康人赤血球を， $3.8 \%$ クエン酸ソーダ $0.1 \mathrm{ml}$ 添 加で採取し, phosphate buffered saline (PBS pH 7.0) にて 3 回洗浄し, 約 $2 \%$ 赤血球浮遊液になる上うに調整 
後，先に作成した抗原液と等量で混合し， $37^{\circ} \mathrm{C} 30$ 分間， 恒温槽で振湯 incubateする。これをPBSで 3 回洗浄し て，再び PBS で $2 \%$ 赤血球浮遊液心調整したものを感 作赤血球として使用した.

c ) 抗体価の測定

$56^{\circ} \mathrm{C} 30$ 分間 incubate に上り非働化した被検血清およ び尿を microplate (Cooke Engineering Co) 上で2 培希 釈を行ない，先の感作赤血球を等量 $(50 \mu \mathrm{l})$ 加克, $37^{\circ} \mathrm{O}$ 3 時間 incubate 後, $4{ }^{\circ} \mathrm{C}$ で 1 晚放置した後凝集反応を 観察した．以上の概略を図1 亿示す。

2. 尿中細菌の分離招よび定量培養

分離用培地としては，ドリガルスキー改良培地， HI 寒天培地, NAC 寒天培地, SF 培地 (以上栄研), DNA 寒天培地（日水）を用い，尿を隇菌水にて，10 $0^{-2}, 10^{-4}$, $10^{-6}$ に希瀵しその $0.1 \mathrm{ml}$ を検体につき各 2 枚ずつの培地 に添加し， $37^{\circ} \mathrm{C} 20$ 時間培言する. 菌数の算定は，ドリガ ルスキー改良培地と HI 寒天培地での集落数を平均し た。

3. Recoated. antibody coated bacteria $(\mathrm{R} \cdot \mathrm{ACB})$ の検出

前述の如く分離した菌株を，TSB にて增殖させ被覆 抗体の除去を扣こない， その後 PBS（pH 7.2）にて洗 浄後, プレパラート上で空気乾燥させ笁抹標本を作成 した後，アセトンにて固定する. 次に, Minicon-B 15 (Amicon) 飞て25倍濃縮させた検体尿 $0.2 \mathrm{ml}$ で上記標 本と反応させ， $37^{\circ} \mathrm{C} 30$ 分間 incubate する.ついで PBS で free の尿中抗体を除去後, Behringwerke 社製の市販 の䖢光標識抗血清 anti IgG，IgA，IgM $0.2 \mathrm{ml}$ で treat 乙同様 incubate する. PBS で充分洗浄した後, 䖢光顕 微鏡で観察する. S-IgA の観察については，正確を期す るために，蛍光標識抗 S-IgA 血清を用いないで, Anti-SC (free secretary component) で treat 後, 蛍光標識抗ウ サギ・ヤギ血清 (FITC-labelled anti-rabbit $\gamma$-globulin of goat : Behring werke 社) を用いた。この場合， 3 抗 体法になるが，第 1 抗体反応時は正常人尿を用いて第 1 コントロールとし，第 2 抗体使用時は, normal rabbit serum を用い，第 3 抗体使用時惊， non-labelled antirabbit $\gamma$-globurin of goat origin をそれぞれのコントロ ールとした.

以上の操作の結果，観察し得た細菌を，原尿の沈查で 作成する Thomas $^{3)}$ の antibody coated bacteria (以下 $\mathrm{ACB}$ ) に対して, recoated. antibody coated bacteria (以 下 $\mathrm{R} \cdot \mathrm{ACB}$ ) と称する。このう方，分離菌化尿中抗体
を被覆させたものを，Urine-recoated ・ antibody coated bacteria（以下 U-R ・ACB）と称し，血清を用いた場合， Serum-recoated $\cdot$ antibody coated bacteria (以下 S-R . $\mathrm{ACB}$ ) 之呼称する. 以上, U-R ・ ACB 作成の概略につ いて述べたが，S-R・ACB 作成操作も同㥞で括る（図 2).

図 $2 \mathrm{R} \cdot \mathrm{ACB}$ 検出法

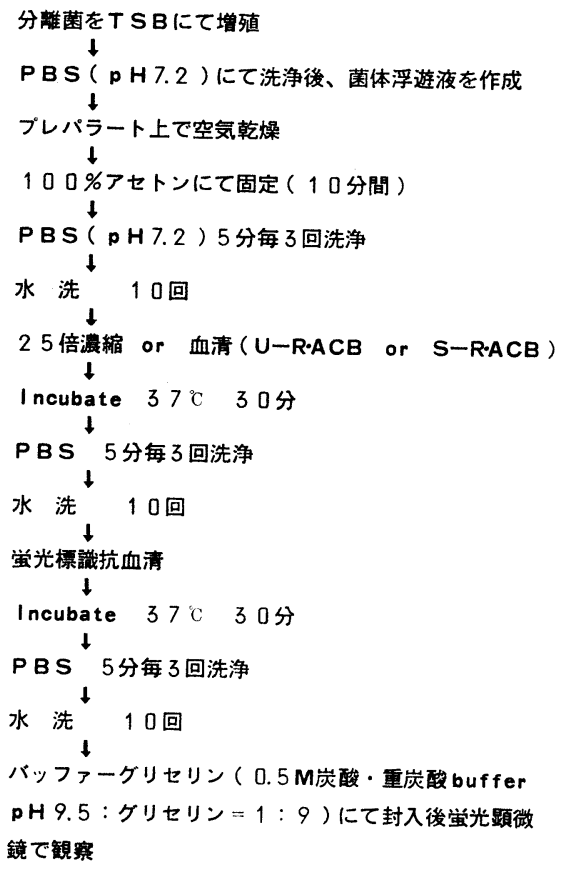

4. 尿中免疫グロブリンの測定

尿中免疫グロブリンの測定に関しては，栗山4゙ が開発 した Enzyme-linked Immunosorbent Assay (E.L.I.S.A.) 法に基づいた。概略を栗山の論文から引用し図 3 に示 与。すなわ方，検体を $10,000 \mathrm{rpm} 10$ 分間遠心分離後そ の上清を用い，0.1MPB pH 7.0で 2 倍希釈後，このう らの $0.1 \mathrm{ml}$ 飞 5 10倍希釈した不溶化抗体 (Ab-BrCN Sepharnse 4B) $0.1 \mathrm{ml}$ を添加して 1 時間室温で incubate する.ここへ50〜100倍希釈した pox 標識抗原 (Ag-pox) を $0.1 \mathrm{ml}$ 加光，室温で 2 時間 $4{ }^{\circ} \mathrm{C} て ゙ 12$ 時間 incubate 寸 る.この後 $0.5 \mathrm{ml}$ の $\mathrm{PB}$ を加光て, 3,000 rpm 30分間遠 心分離 $し$, 上清 $0.2 \mathrm{ml}$ 飞 Pox reagent $(1 \%$ O-dianisidine and $\left.0.3 \% \quad \mathrm{H}_{2} \mathrm{O}_{2}\right) 3 \mathrm{ml}$ を添加して 1 時間室温で 反応後の OD 403を測定する. S-IgA の測定も，これと 同榚に，anti-SC を用いて測定した。また，両側尿管皮 
図 3 E.L.I.S.A. 法による尿中免疫グロブリンの測 定

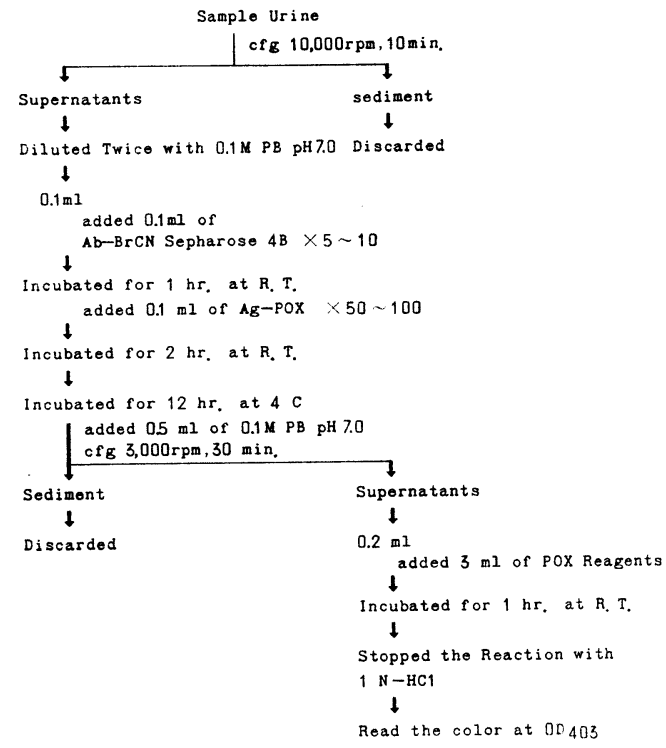

膚瘻の場合は，分腎尿毎に原尿にて測定した。

\section{実験成結}

1. 患者自己糞便に対する血清抗体価

今回の検討対象症例が，尿路变更前に担癌状態であっ たことが多いことから，血清抗体価陽性限界值の見当を つけるため, 患者の糞便より分離された菌株の抗体価の 測定を試みた。 8 症例より 4 菌種，14株分離され，E. coli が 8 株と最も多く認められた. 血清抗体価は表 1 の 如く，最高64倍であった. したがって尿路感染菌株に対 する抗体価陽性限界值を128倍とした（表 1).

2. 血清抗体価変動因子の検討

慢性尿路感染症患者に於いて，経過中に認められた尿 路分離菌に対する血清抗体価の推移を検討してみると, それぞれに対する血清抗体価は, 約半年の経過を観察し た範囲では，高抗体価を持続させる菌株以外に，新たに 上昇する菌株を認めた（図 4)）。慢性の抗原刺激のなか にあっても抗体価の上下動を示す事実より，抗体価に変 動をもたらす因子の検討が必要である.

a ）分離菌別，尿瘦別血清抗体価

そこで先ず，分離菌別に経過観察中の最高血清抗体価 の検討を行なった(図 5). 資料の統計的解析はWilcoxon の順位和検定を用いて行ない，主要な検定結果は図に示 した. 分離菌のうら代表的な E. coli と, 緑膿菌を除く ブドウ糖非発酵性グラム陰性嘲菌（NF-GNR）の抗体価
表 1 糞便分離菌と抗体価

\begin{tabular}{|c|c|c|c|}
\hline 症例 & 糞便分離菌 & 菌量 (cell/g) & 抗体価 \\
\hline \multirow{3}{*}{ A.M. } & E. coli & $2 \times 10^{7}$ & 32 \\
\hline & P. mirabilis & $5 \times 10^{4}$ & 4 \\
\hline & Enterbacter & $1 \times 10^{6}$ & 4 \\
\hline S.O. & E. coli & $1 \times 10^{8}$ & 8 \\
\hline \multirow{2}{*}{$\mathrm{K} \cdot \mathrm{A}$} & E. coli & $1 \times 10^{7}$ & 64 \\
\hline & Enterobater & $1 \times 10^{5}$ & 8 \\
\hline \multirow{3}{*}{ H. T. } & E. coli & $6 \times 10^{7}$ & 32 \\
\hline & K. pneumoniae & $3 \times 10^{6}$ & 32 \\
\hline & Enterobacter & $1 \times 10^{6}$ & 8 \\
\hline \multirow{2}{*}{ A. M. } & E. coli & $2 \times 10^{7}$ & 16 \\
\hline & Enterobacter & $1 \times 10^{7}$ & 8 \\
\hline K.W. & E. coli & $1 \times 10^{7}$ & 8 \\
\hline K. K. & E. coli & $2 \times 10^{7}$ & 8 \\
\hline G.S. & E. coli & $3 \times 10^{6}$ & 64 \\
\hline
\end{tabular}

图 4 症例 55才合 Bladder cancer (Total cystectomy with blt. ureterocutaneostomy S. 49.6)

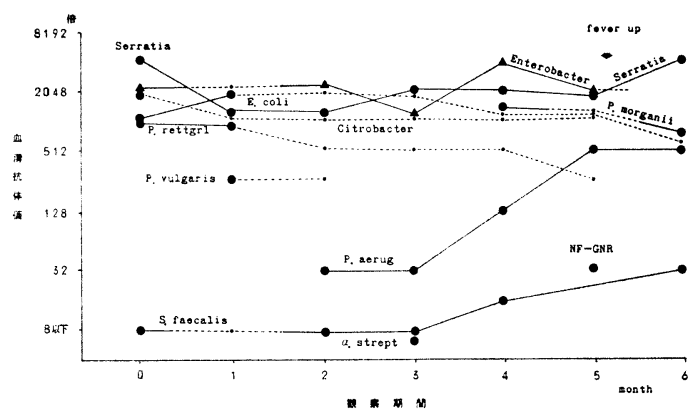

図 5 菌種別及び留置部位別最高血清抗体価

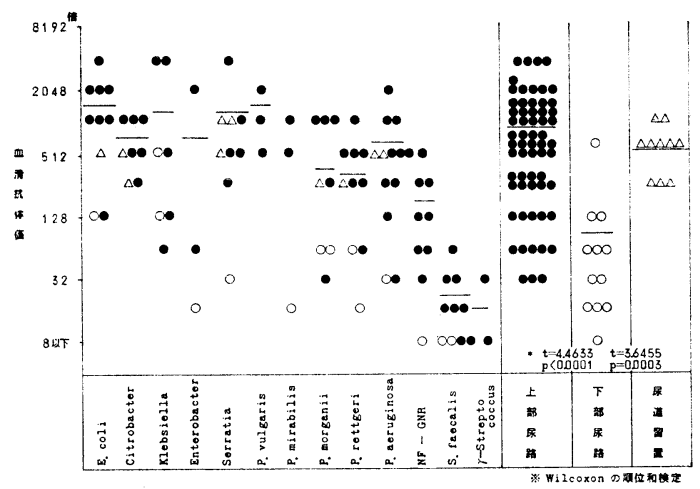


の検定は， $\mathrm{t}=3.0080, \mathrm{p}=0.0026$ となり， $\mathrm{S}$. faecalis と の検定では $\mathrm{t}=3.8142, \mathrm{p}=0.0001$ となって，いずれも 危険率 $1 \%$ 以下で有意の差を諗めた。立た，NF-GNR と S. faecalis 間の検定でも $\mathrm{t}=2.8184, \mathrm{p}=0.0048$ とな つて有意の差であつたが，E. cnli と，S. faecalis，NFGNR 以外の菌群との間に有意の差を認めなかつた，以 上より，グラム陽性球菌と NF-GNR 以外は，すべて高 抗体価を示与傾向を認めた（図 5 )。また，低抗体檤を 示す 2 群のなかで，NF-GNR と，S. faecalis を代表とす るグラム陽性球菌との間にも有意差を認めた。グラム陽 性菌については，後に考按の部分で触孔るが，Hemagglutination 法で測定する限り，低抗体価しか示さない。 これは, グラム陽性球菌が単なる污染菌で尿路感染症の 起炎菌たり得ていないといらよりも，むしろ測定法に問 題があるのではないかと考光ている。詳細は後てわず る. 以上の見解より， S. faecalis に代表されるグラム陽 性球菌群を以下の検討対象からはずし別取り扱らこと ヒする.

次に，尿瘦別に抗体価の検討を行なってみると，グラ ム陽性菌を除いて図 5 の右端のコラムに示した如くで㐫 る.ここでも Wilcoxon の順位和検定を行なってみる と, 上部尿瘦と下部尿瘦間の最高血清抗体価には, $\mathrm{t}=$ $4.4633, \mathrm{p}<0.0001$ となつて危険率 $1 \%$ 以下で有意の 差を認め, 下部尿瘻と尿道留置閒でも $\mathrm{t}=3.6455, \mathrm{p}=$ 0.003 で同様有意の差艺認めた。上部尿瘦と尿道留置間 では, $\mathrm{t}=0.3372, \mathrm{p}=0.7359$ で有意の差ではなかつた が，一応，尿㿉間の抗体価の比較では，上部尿瘦が最も 高く，ついで尿道留置，下部尿瘻の順で抗体価を示した と言えよう、すなわち，各尿路を免疫反応の場として考 光た場合，上部尿路が最も強い反応の場と言えよう。ま た，尿道留置の 5 症例はいずれる男子で，下部尿瘦と抗 体価で差を認めたのは，前立腺部が免疫反応の場として 何らかの役割を荷なつていると考兄られる．以下の検討 で各尿癭間での抗体価の差を除外するために, 検討対象 を症例の一番多い上部尿瘦の慢性腎孟腎炎症例の久とす 万.

b ) 薬剂耐性と血清抗体保

検討対象の上部尿瘐（尿管皮虐瘦, 腎瘦）症例は, 尿 路変更後の経過期間は 1 年から 6 年にわたつており，こ の間各種抗生剂にさらされている，そこで Disk 法でみ た薬剤耐性別に最高血清抗体価を比較してみた。な抢, 薬剤耐性としたものは，Disk 感受性で（一）を示した ものを採用した。ペニシリン耐性株とアミノ配糖体系薬
剤耐性株の抗体洒の間の検定は, $\mathrm{t}=3.3930, \mathrm{p}=0.0007$ となつて危険率 $1 \%$ 以下で有意の差を認めた. 全ての群 間の検定結果は，アミノ配糖体系抗生剂而性以外は差を 認めなからた（図6）。

c) 菌数と血清抗体何

図 7 は, 混合感染症で可能な限り感染菌を分離し, 分離菌別の菌数と抗体価の測定值をプロットしたもの である. $10^{4} / \mathrm{ml}$ 以下で分雄された菌は手技上わずか 8

図 9 薬剤耐性と最高血清抗体俩

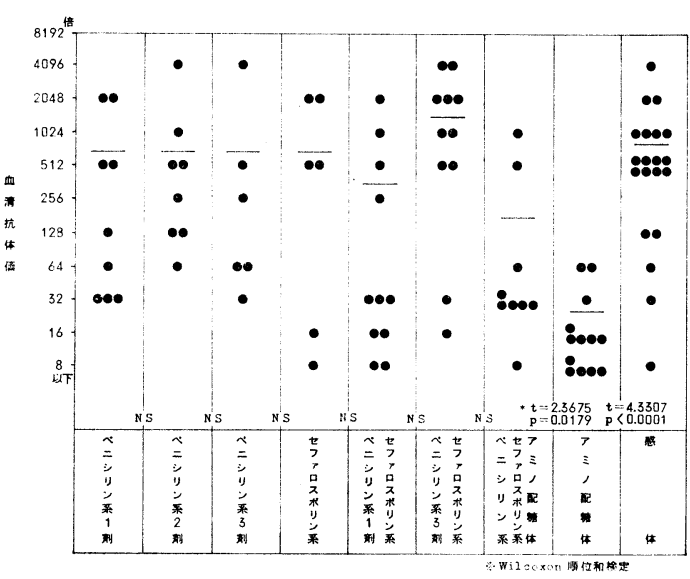

図 $i$ 菌数と血清抗体值

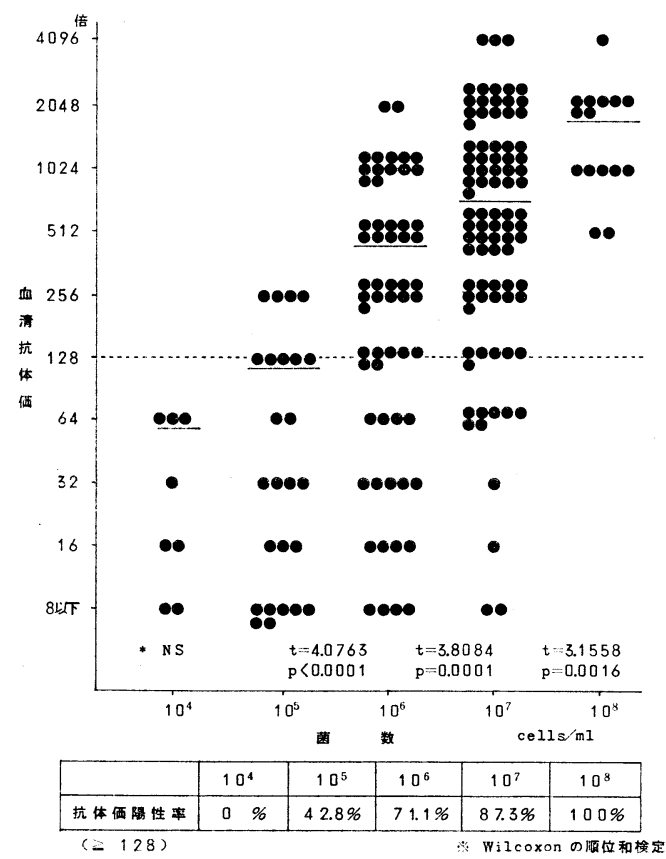


株に過ぎないここでも菌数毎に抗体価の群間比較を Wilcoxon の順位和検定で行ならと， $10^{4} / \mathrm{ml}$ と $10^{5} / \mathrm{ml}$ の間では, $\mathrm{t}=0.7912, \mathrm{p}=0.4288$ となて有意の差を認 めなからたブ, $10^{5} / \mathrm{ml} と 10^{6} / \mathrm{ml}$ 間は, $\mathrm{t}=4.0763, \mathrm{p}<$ 0.0001 となり $1 \%$ 以下の危除率で有意差觉認めた。下 $10^{6} / \mathrm{ml}$ と $10^{7} / \mathrm{ml}, 10^{7} / \mathrm{ml}$ と $10^{8} / \mathrm{ml}$ 間で当同様に有意の 差を認めた。また128倍以上を抗体洒陽性とした陽性率 で各群間の比較を行ならと，陽性率は $10^{4} / \mathrm{ml}$ は $0 \%$ 菌数の増加とともに陽性率は上昇し，108 order では 全例陽性となつた。

次に, 菌量の推移之血清抗体価の変動老娭討して及 た. 2 週の間隔を持つ或る 2 時点で困量の变化と抗体価 の変動を図 8 に示寸。抗体価の上昇を示したものは上问 きの生，下降走示したものは下向さの矢印，とくに 2 管以上の変動を認めたものは太字で示した。また破線 は, 菌数の変動が 1 order 以内示与。多くの場合は, 菌量の変動が 1 order 以内に留まること, 1 order 以上の 変動では菌量の変動に従つて血清抗体価が上下動与る傾 向を認めた。

図 8 菌量の推移々血清抗体洒の変動

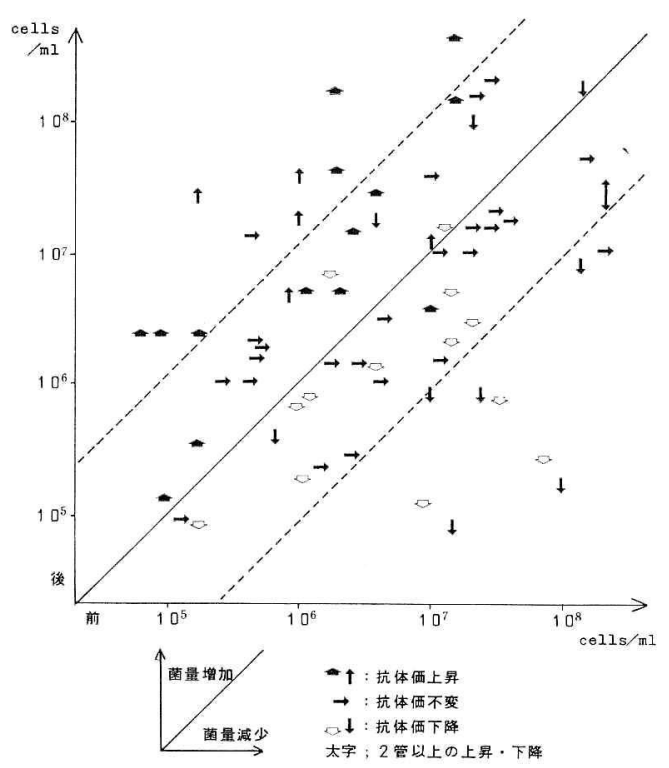

3. 再生 $\mathrm{ACB}(\mathrm{R} \cdot \mathrm{ACB})$ と血清抗体価の検討

図 9 は, Klebsiella pneumoniae の U-R ・ ACB を蛍光 顕微鏡下で400倍にて観察したものである。特徴は，原 尿を用いた $\mathrm{ACB}$ と異つて，尿中白血球等の細胞成分が 染色されないことである。
図 $9 \times 400$ U-R.ACB (K. pneumoniae)

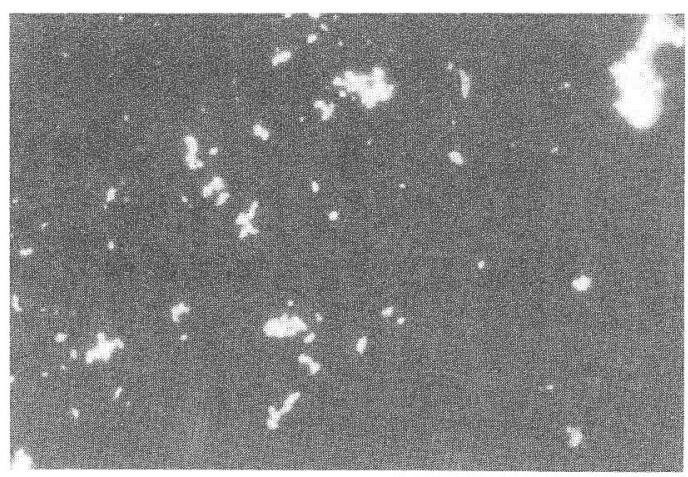

まず抗 $\mathrm{IgG}$ 血清を用いた $\mathrm{R} ・ \mathrm{ACB}$ の検討では，分離 菌66株中，56株が S-R ・ACB 陽性で陽性率は80\%であ つた（図10）。むた S-R・ACB 存，监光の発し具合によ り $(-) \sim(+),(+),(H) \sim(H)$ の3 段階に分け, 血清抗体価の偏り具合老，Wilcoxon の順位和検定て 倹討してみると, $(一) \sim(+)$ 群と $(+)$ 間では, $\mathrm{t}=$ $3.3641, \mathrm{p}=0.0008$ となつて $1 \%$ 以下の危険率で有意差 を認わた。しかし $(+)$ 群と $(H) 〜(H)$ 群の間では, $\mathrm{t}=0.2237, \mathrm{p}=0.8230$ となつて有意差を認めなかつた. したがつて，(十）以上を陽性と判定した。なた，S-R・ ACB 陽性群々陰性群の血清抗体価陽性率を比較してみ 石と，陽性群は56株中51株が抗体価陽性でその陽性率は 91.1\%であり，陰性群のそれは10株中 3 株30\%であつ て, S-R・ACB 陽性群で明らかに高抗体洒を示した。次 飞U-R · ACB は, 分離菌62株中, 48株が陽性で陽性率 は74\%であつた。李た，U-R・ACB と血清抗体価の関 倸は，U-R・ACB (一) （士）群之 (十) 群間々の検定 結果は, $\mathrm{t}=0.8089, \mathrm{p}=0.4186$ で有意差を認めず, $(+)$ 群と（H)〜(H) 群間も同様に有意差を認めなからた。 これを抗体価陽性率で検討してみると, 陽性群は48株中 38株79\%であり，陰性群は，16株中13株陽性で抗体価陽 性率は80\%となって, 両群間でやはり血清抗体価に差を 認めなかった．以上の成績から U-R ・ ACB の抗体（尿 中抗体) が単なる血中からの漏出抗体ではないことが示 唆された。亦た，抗 IgG 血清孝用いた S-R ・ ACB，U一 $\mathrm{R} \cdot \mathrm{ACB}$ のいずれの陽性率も70 80\%と高く，血清中， 尿中とも IgG が重要な役割を荷なつていると考光られ 万(威10).

抗 IgA 血清を用いた検討では，S-R・ACB，U-RACB の陽性率はそれぞれ，80\%，55\%であつた。しかし血清 


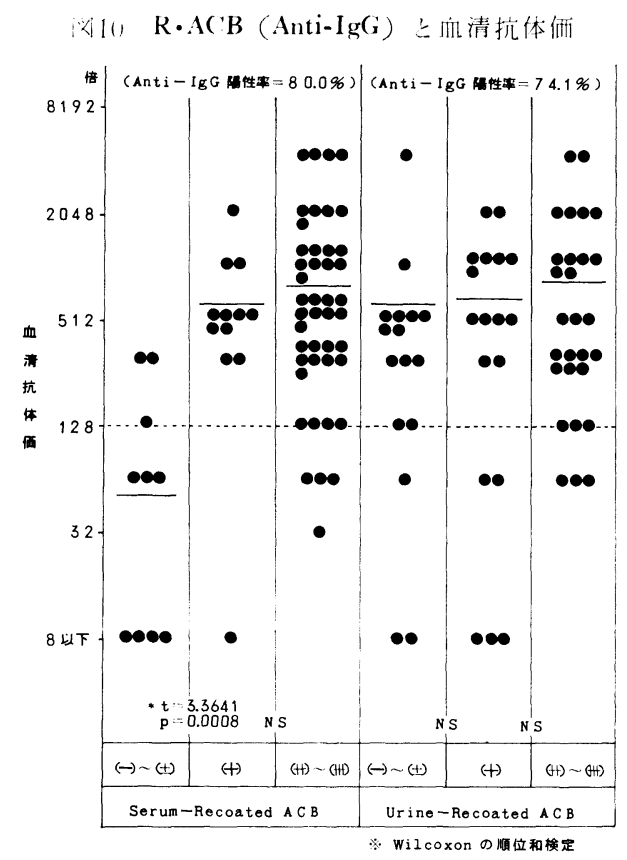

抗体価との関係は, S-R ・ACB の陽性群と院性群間での 娭定結果で, $\mathrm{t}=1.5813, \mathrm{p}=0.1138$ となり, U-R・ACB のそれは $t=0.3082, p=0.7579$ となつていずれも血清 抗体価との圆係は明らかではなかつた（沙11）。

また IgM の場合では, S-R・ACB 43.8\%, U-R・ $\mathrm{ACB} 15.6 \%$ と陽性率は前 2 者に比してはるかに低值を ホしたＳ-R・ACB 陽性群と陰性群との間で血清抗体侕

$$
\text { 以 } 11 \text { R.ACB (Anti-IgA) 上血清抗体侕i }
$$

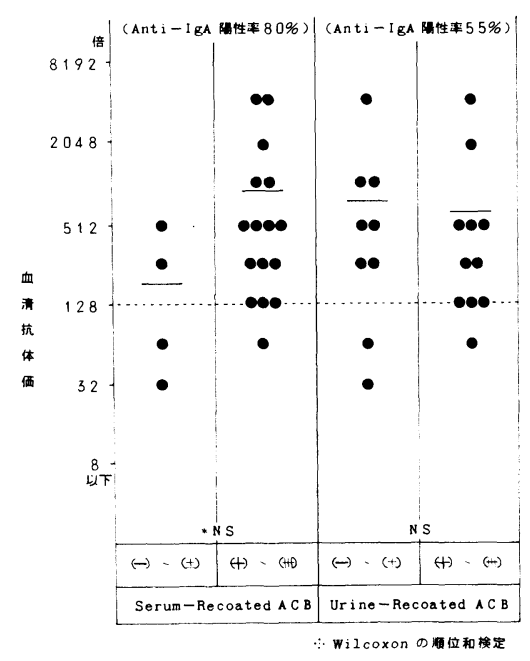

二の関係は, $\mathrm{t}=0.3085, \mathrm{p}=0.7577$ 上なり有意の差を認 わザ，U-R・ACB \&问様の結果であ一た。慢性疗路感

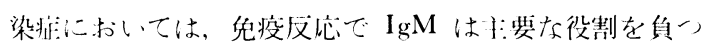
こいないこ上がわが(瓯12).

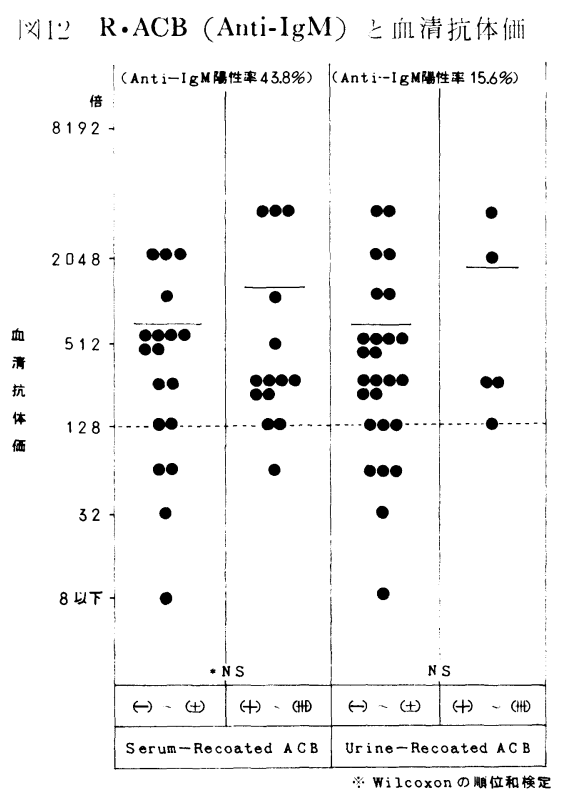

抗 SC IIII清を用いた， S-IgAの R・ACB の検討では, S-R・ACB では陽性率が $30 \%$ IgM の場合より更に低 率であるが，U-R・ACB の陽性率は $80 \%$ と高值を示し， 尿中局所免疫における役割は無視出来ない。また血清抗 体価との関係は, S-R ・ ACB 晹性群と陰性群の検定結果 は $\mathrm{t}=1.2499, \mathrm{p}=0.2113$ となつて有意差を認めず，血清 抗体価と, S-IgA の S-R・ACB との間には明らかな関係 を铝めなかいた。同様に U-R・ACB との関係でも有意 差を認めなかつた（図13）。

以上より，抗 IgG 血清を用いた S-R・ACB の陽性， 陰性と血清抗体価の多寊がよく相関することかっら, S-R ・ ACB は血清抗体価の定性反応であるこょ，慢性腎血婜 炎に於いて血清抗体価の主役は IgGであることが示唆 された。また，U-R・ACB で陽性率が高值を示した IgG， S-IgA が咸中局所免没でかなり重要な役割を荷なつてい ると考えられる。

4. U-R ・ ACB と疗中免疫グロブリンの検討

$\mathrm{U}-\mathrm{R}$ ・ ACB に結合する㽷中兔疫グロブリンは, U-R • $\mathrm{ACB}$ 作成時のコントロールで既に specific なものと考

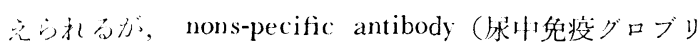


図13 R・ACB (Anti-SIgA) と血清抗体価

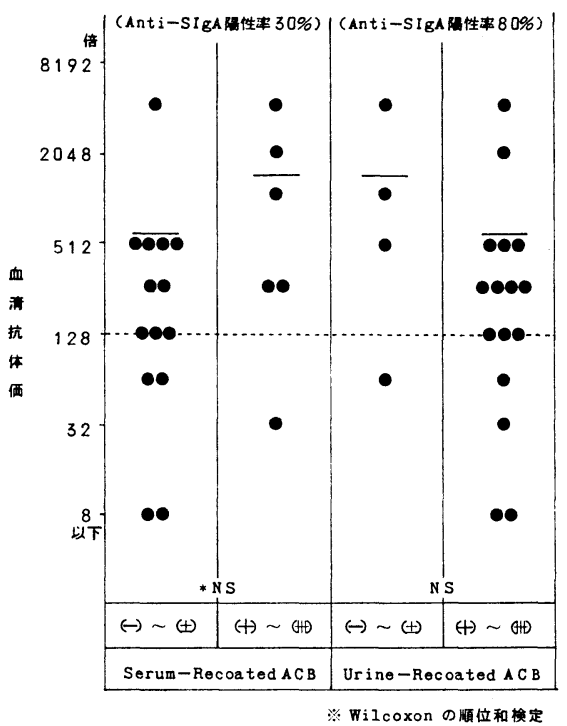

ソ)が単に cover しているものかもしれないとの観点か ら，尿中免疫グロブリン量と，U-R・ACB の関係を検 討した。

まず，慢性カテーテル留置症例の尿中免疫グロブリン 值を図14に示した，正常值は，教室の栗山4の測定值に 基づいた。印は腎瘦および尿管皮膚瘦の慢性腎盂腎炎 症例である。尿中 IgG は，上部尿瘦検討症例 12 例中 11 例迄が, 正常值 $352 \mu \mathrm{g} / \mathrm{dl}$ 以上で平均 $27,214 \mu \mathrm{g} / \mathrm{dl}(27.2$ $\mathrm{mg} / \mathrm{dl})$ を示した．IgA は14例中10例が正常值 $122 \mu \mathrm{g} / \mathrm{dl}$ 以上を示し, 最高は $1 \mathrm{mg} / \mathrm{dl}$ 以上の高值を示した 1 例を 認めた. 尿中 S-IgA は, $1 \mathrm{mg} / \mathrm{dl}$ 以上が14例中 8 例で, $10 \mathrm{mg} / \mathrm{dl}$ 以上の異常高值を示した 2 例は，同一症例の右 腎尿と左腎尿でそれぞれ $26 \mathrm{mg} / \mathrm{dl} ， 16.5 \mathrm{mg} / \mathrm{dl}$ であつた。

図14 カテーテル留置症例の尿中免疫グロブリン
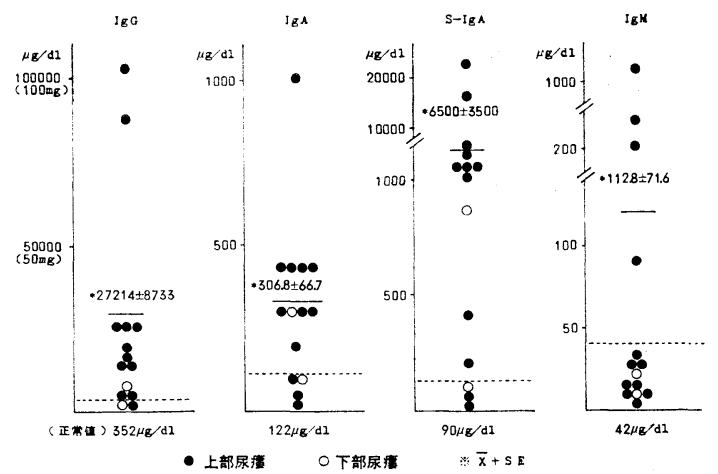

カテーテル留置症例の S-IgA の平均は, $6,500 \mu \mathrm{g} / \mathrm{dl}$ ( $(6.5$ $\mathrm{mg} / \mathrm{dl}$ ) で正常值の $90 \mu \mathrm{g} / \mathrm{dl}$ を大きく上まつた。一方, 层中 IgM は，14例中10例迄が正常值 $42 \mu \mathrm{g} / \mathrm{dl}$ 以下に留 まり，異常值を示したのは 4 例のみであつた. 総じて, 慢性腎盂腎炎症例では，尿中免疫グロブリン值はいずれ も高值を示した。

次に，尿中免疫グロブリンとU-R A ACB との関係を 図15に示した。図の症例は全て，尿管皮膚瘦の慢性腎盂 腎炎の症例であり，いずれの症例も混合感染例で複数 の菌が分離されている. 成績は分離菌毎に dot map で 示した。まず IgG の検討では, U-R・ACB 陽性群22株 中，19株が正常以上の免疫グロブリン值を示す尿路から 分離され, 平均 $30 \mathrm{mg} / \mathrm{dl}$ でめつた。陰性群は8株で, 平 均 $23 \mathrm{mg} / \mathrm{dl}$ であつた. 陽性群と陰性群の尿中免疫グロブ リン值の $\mathrm{t}$ 検定を行ならと, $\mathrm{p}=0.6080$ となつて両群間 に有意の差を認めなかつたＩgG のコラム上方にある 5 コのdot は同一患者の左右の疗管皮膚瘦から分離された 菌で，詳述すると，右腎尿の尿中 IgG は $112 \mathrm{mg} / \mathrm{dl}$ で, 分離菌は，K. pneumoniae と E. coli でありいずれも U-R ・ ACB 陽性で少つた。左腎の尿中 IgG は $89.6 \mathrm{mg} / \mathrm{dl}$ で, 分離菌のうち K. pneumoniae, E. coli は U-R • ACB 陽性で, P. aeruginosa は陰性であつた.すなわ ち，IgG の U-R ・ ACB の陽性・陰性は，尿中 IgG の 多寡によるよいらょりも，分離菌が尿路で感作されたか 否かによものと考兄られる.上記 P. aeruginosa は, 或る時点に抢いては左婜尿路に於ける起炎性への関与は 少ないと言えよう。同様のことは，コラム下段にみられ るが如く，尿中 IgG が低值を示していても U-R・ACB 陽性という症例でも言える。

IgA についても，U-R・ACB 陽性群と陰性群で尿 中 IgA 值の平均は，それぞれ $332 \mu \mathrm{g} / \mathrm{dl} ， 220 \mu \mathrm{g} / \mathrm{dl}$ とな

図15U-R・ACB と尿中免疫グロブリン

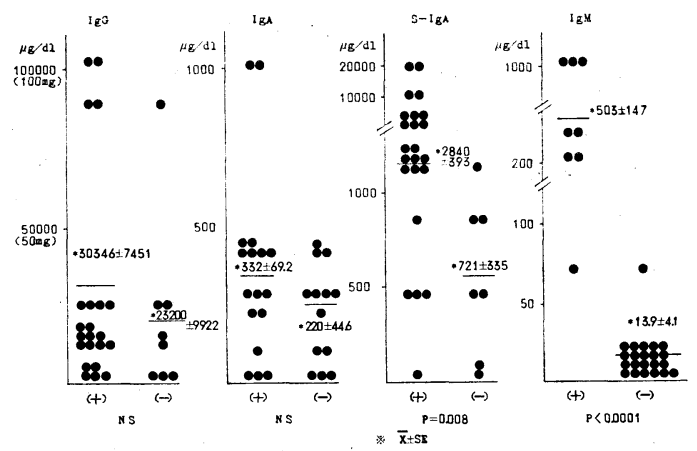


り $\mathrm{t}$ 検定で有意差を認めなかつた $(\mathrm{p}=0.2234)$. IgA に ついても， U-R・ACB 陽性，陰性は尿中免疫グロブリ ン量とは無関係に, 分離菌側の条件の夕で感作, 非感 作される結果基くものと考光られる。一方，S-IgA と IgM 飞ついては, U-R・ACB 陽性群と陰性群で明らか な差を認めた。 S-IgA の U-R・ACB 陽性群23株が分離 された康中 S-IgA の平均は, $2,840 \mu \mathrm{g} / \mathrm{dl}$ であり，陰性 群のそれは $721 \mu \mathrm{g} / \mathrm{dl}$ で, $\mathrm{p}=0.0081$ となつて両群間で 危険率 $1 \%$ 以下で有意差を認めた。 IgM でも同様に， 陽性群の平均は $503 \mu \mathrm{g} / \mathrm{dl}$ で陰性群のそれは, $13.9 \mu \mathrm{g} / \mathrm{dl}$ となり， $\mathrm{p}<0.0001$ と著明な差を認めた。また $\operatorname{IgM} の$ U-R・ACB が陽性を示した 8 株は，4尿路 3 症例から 分離されたが，採尿時にとくに慢性腎㙉腎炎の急性増覀 期を思わせる episode は認めていない。

以上をまとめると，IgG，IgA では U-R ・ ACB 陽性， 陰性群間に免疫グロブリン量の量的差を認めないが, S-IgA，IgM では，U-R・ACB 陽性群で免疫グロブリン は高值を示した。

\section{R・ACB と尿中抗体価の検討}

尿中抗体価の検討は，U-R - ACB 検出時に25倍濃縮 尿を使用したため，尿中抗体価との関係を検討する必要 性から，抗体価測定に市たつても25倍濃縮尿を第 1 管と して使用した．尿中抗体価の表示は，25倍漕縮尿を第 1 管とし，倍々希釈の管数で行ない，第 5 管がほぼ原尿に 相当する．また表中に記載の U-R ・ ACB 快抗 IgG 血清 によるものである.

尿中抗体価陽性症例は, カテーテル留置慢性腎盂腎炎 12例中，表 2 の如く 3 例（25\%）であつた. 表に示した 3 症例は, いずれも長期留置カテーテルの慢性腎孟腎炎 症例で, Case 1，3 は雨側尿管皮膚瘦症例で峁り, Case 2 は右腎瘦の症例である. 尿中抗体価の陽性限界值を何 処に膡くかは問題であるが，著者の正常人濃縮尿を用い た 5 例の検討では，第 1 管でも凝集を認めなかつた。し かし，Pearsall ら の)の報告では原尿の 2 倍希釈尿以上で 凝集を認めた場合を陽性としている。これに従うと，渚 者の測定法では 6 以上になる。この見解に従つて表の成 績をみてみると，尿中抗体価陽性（6以上）株は 8 株認 め全株とも U-R ・ ACB 陽性であつた。逆に, U-R・ACB 陽性でありながら尿中抗体価㓌性例は，抗体価測定法に 問題のある S. faecalis を除くと，11株中 4 株（36\%) 認めた。概して，尿中抗体価と，U-R・ACB はよく相 関するようで，S-R・ACB の陽性，陰性とは関俰が認め られなからた。また各症例は混合感染例であるが，表の
表 2 尿中抗体価と $\mathrm{R} \cdot \mathrm{ACB}$

(Case 1)

\begin{tabular}{|c|c|c|c|c|}
\hline \multirow{2}{*}{ 分 類 莯 } & \multirow{2}{*}{ 血清抗体㑛 } & \multirow{2}{*}{ 层中抗体価 ${ }^{*}$} & \multicolumn{2}{|c|}{$\mathrm{R} \cdot \mathrm{ACB}$} \\
\hline & & & serum & urine \\
\hline E. coli & 2048 & 6 & H & $H$ \\
\hline K. pneumoniae $(\mathrm{rt})$ & 4096 & 8 & H & H. \\
\hline$P$. aeruginosa $(r t)$ & 512 & 0 & + & - \\
\hline E. coli (It) & 1024 & 7 & H & tt \\
\hline C. freundii (It) & 1024 & 6 & HH & H \\
\hline K.pneumoniae & 2048 & 7 & $\mathrm{HH}$ & H. \\
\hline
\end{tabular}

*：25倍濃縮尿を第 1 管として倍々希釉の管数で表記 (Case 2)

\begin{tabular}{|c|c|c|c|c|}
\hline & \multirow{2}{*}{ 血清抗体佂 } & \multirow{2}{*}{ 尿中抗体傮 } & \multicolumn{2}{|c|}{$\mathrm{R} \cdot \mathrm{ABC}$} \\
\hline & & & \multicolumn{2}{|c|}{ serum urine } \\
\hline Serratia & 1024 & 7 & ttt & t \\
\hline P. morganii & 128 & 0 & H & \pm \\
\hline S. faecalis & 32 & 0 & $H$ & H. \\
\hline \multicolumn{5}{|c|}{$\begin{array}{l}\text { * : } 25 \text { 倍濃縮尿を第 } 1 \text { 管として售々希积 の管数で表記 } \\
\text { (Case 3) }\end{array}$} \\
\hline \multirow{2}{*}{ 分 離 菌 } & \multirow{2}{*}{ 血清抗体洒 } & \multirow{2}{*}{ 尿中抗体価＊ } & \multicolumn{2}{|c|}{$\mathrm{R} \cdot \mathrm{ACB}$} \\
\hline & & & serum & urine \\
\hline C. freundii (rt) & 512 & 0 & H & - \\
\hline P. mirabilis $(\pi t)$ & 256 & 0 & it & -- \\
\hline P. morganii $(r t)$ & 1024 & 2 & + & + \\
\hline P. rettgeri (rt) & 256 & 3 & H & + \\
\hline $\mathrm{S}$. faecalis $(\mathrm{rt})$ & 16 & 0 & + & \pm \\
\hline C. freundii (It) & 512 & 0 & H & - \\
\hline Enterobacter (It) & 512 & 0 & $\mathrm{H}$ & + \\
\hline P.vulgaris (It) & 256 & 0 & - & - \\
\hline P. rettgeri (lt) & 32 & 7 & + & H \\
\hline NF-GNR（It） & 512 & 8 & $\mathrm{H}$ & $H$ \\
\hline
\end{tabular}

*：25倍濃縮尿を第 1 管として倍々希釈の管数で表記

如く分離菌のうち複数の紐菌が 血清抗体価，尿中抗体 価，および R・ACB に陽性にあつて，特定の一菌種に 限つていないことから，分離菌の殆どの菌が起炎性に関 与しているものと考えられる。また血清抗体価が512以 上の抗体価をとる12株中，尿中抗体価陽性例は 7 株（58 \%)であつて陰性例も5株認められた。逆に Case 3 の P. rettgeri のように血清抗体価が32と低值を示したもの で尿中抗体価が 7 と陽性になる例も認められた。血清抗 体価と尿中抗体価が此較的同調する場合も市るが，雨者 は相関するとは言い難い。 


\section{考按}

一般に Indirect hemagglutination に括いて細菌菌体 成分の中，多糖体分画が感作抗原となること，および氺 路感染症に颃いて血中抗体が蚞出されることが知られて いる. 本法は Neter ${ }^{6)} ら$ (1952) が, antibody の検索に 細菌凝集反応に替る方法として紹介して以来，一般的に なつた。血中抗体価を語る場合，生体側からみると防禦 能の程度であるが, 微生物側からみると, 生体側への侵 襲の反映であつて起炎性の軽重の指標になると考壳られ 子.

1. 血中抗体価陽性限界値について

Indirect hemagglutination 法にて，㽷路感染症で起炎 性を言々する場合, 陽性限界值が問題になつてくる.山 本 ${ }^{7)}$ は, 自己糞便分離菌に対する血中抗体価で80倍以上 は 1 例も認めなかつたとして，陽性限界値を80倍以上と している. Needle ${ }^{8)}$, Pearsall ら ${ }^{5)}$ は, 正常人コントロ ールの95\%以上が128倍以下を示したとしている。また Percival ら ${ }^{9)}$ ，抢よび Pujol ら ${ }^{10)}$ は，160倍を限界值と している.一方上田ら ${ }^{11)}$ の報告では，コントロールは25 倍以下としていて諸家の報告毎に一定していない。著者 も, 今回の検討対象が尿路変更患者が主体で, 術前に担 澏状態であつて，免疫反能に修飾があるかもしれないと 考え, 患者の自己糞便分離菌に対する血清抗体価を測定 してみた.8症例で分離された14株は全て64倍以下に留 まつたので，著者の場合は，128倍以上を抗体価陽性限 界值の目安とした。諸家の報告をみても128倍前後が一 応妥当な線と考えられる。

2. 分離菌別血清抗体価について

慢性尿路感染症で分離される菌の 血清抗体価は，S. faecalis で代表されるグラム陽性球菌と NF-GNR 以外 は等しく高抗体価を示したことより，上記 2 組の例外を 除くと, 分離菌間で起炎性に偏りはないと言えよう。し かし, Cater ら ${ }^{12)}$ は Proteus が E. coli よりよく反応す ること，Aerobacter で抗体価の上昇を認めないことを 報告していることや, Scarpelli ら ${ }^{13)}$, Pseudomonous の Immunogenecity が高いとの報告等，グラム陽性球菌以 外で菌種間での抗体価の差を強調する報告も認められ る.著者が検討した範囲では，S. faecalis は菌量が充分 のもとで分離されて打りながら，最高血清抗体価は全て 64倍以下であつた。山本 ${ }^{7)}$ の報告でも, S. aureus が40倍 以下，S. epidermidis が320倍と160倍が各 1 株ずつ，多 数は80倍以下に留まつたとしている.そこで山本”゙， グラム陽性菌の作成抗原に問題があるのではないかと考
えたが，家鬼に免疫することで抗原の正当性を確認して いる。そこで著者もまず，抗原作製法の検討を若干試み た。図16は超音波破砕法と加熱法で抗体価の titer を比 較した㬰験成緽である。両者に有意の差を認めない， た， Lancefield ${ }^{14)}$ の指摘により，菌体浮遊液の $\mathrm{pH}$ を

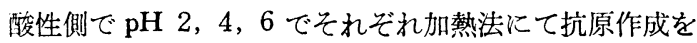
試みたが， titer に差を認めなかつた。な踆性 buffer としては pH 2 の $\mathrm{KCl}-\mathrm{HCl}$ buffer を使用した. 以上よ りグラム陽珄菌の抗原作成方法では差を認めないようで あるので，次に血清抗体価測定法についても若干の検討 を加えた，著者の私見では，混合感染症に於けるグラム 陽性菌の血清抗体価が高值を示さないのは，この菌群が 単なる污染菌というよりも，グラム陽性球菌の菌体抗原 がO型赤血球に感作され難いのではないかと考えてい る.グラム陽性球菌の細胞壁の基本構造が, glycosaminopeptide と teichoic acid の結合体である ことから, アミノ酸のN末端に注目し， $\varepsilon$-aminocaproic acidを spacer とし latex に菌体抗原を化学的に結合させられ ないかと考光，若干の検討を加觉た。本法は原理的にも 方法論的にも問題が残るようで参考データを附するに留 める(図17，18）.この，Immuno latex 法によると， S. faecalis は最高2,048倍迄の測定值を示し，グラム陽 性球菌は単なる污染菌に留まるものではないことが示唆 された．今後の検討が必要であると考えている。

3. 疗瘦別血清抗体価について

尿瘪間の抗体価の上昇程度は，上部尿路留置，尿道留 㯰，下部尿路留置の順となつたが，これは，Hewstone

図16 菌体抗原抽出法の比較

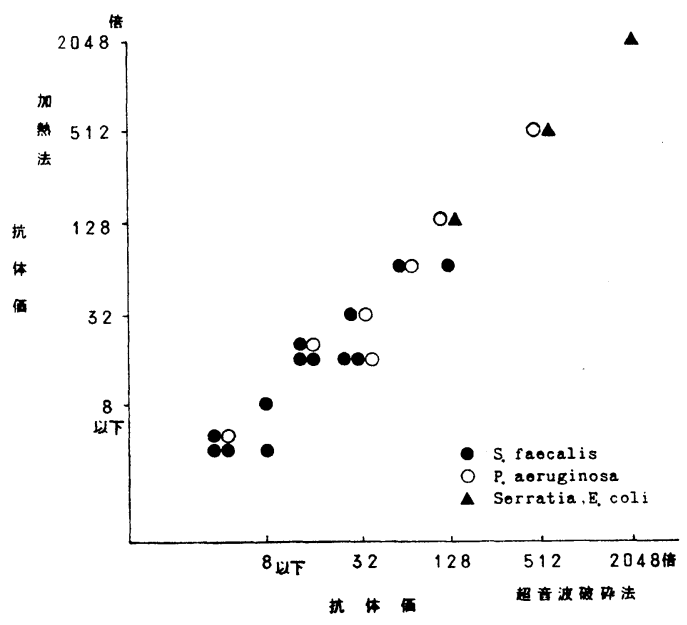


図17 Immunolatex 法

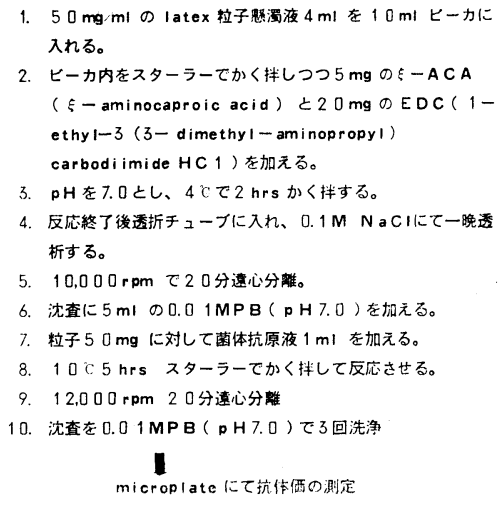

図18凝集反応の担体の比較 (Immuno latex 法と Haemagglutination 法)

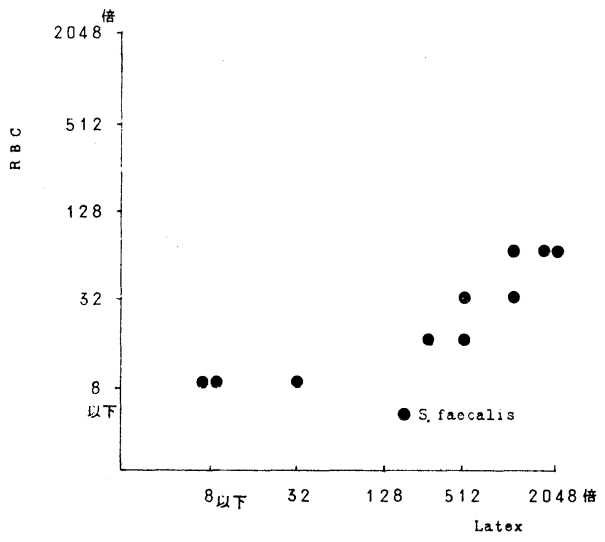

$5^{16)}$, Ehrenkranz $5^{17)}$, Clark $5^{18)}$ の上部尿路感染症 で有意に血清抗体価が上昇するといら成績に一致して、 る，尿道留置例で比較的高抗体価を示したのは，検討対 象が男于のみに限られた長期留置患者であつて，前立腺 部が免疫反応の場として示唆される。これは，ACB の 検出が上部尿路感染症と下部尿路感染症の判別に用いら れる以外に，最近 Jones ${ }^{19)}$ が報告しているように前立腺 炎で ACB 陽性になることを考光あわせると興味深い。 ただ ACB 検出率だけからいうと, Thorley ら ${ }^{20)}$ の報告 では尿道留置例の ACB 陽性率は36\%と必ずしも高くな い.この場合，留置期間の平均が 22 日と比較的短期間で あること，特よび女子症例が含まれているためと思われ る。李た Stamey ら ${ }^{21}$ によると，泉道留犆例の55\%に上 部尿路疾患を合併するとしていることから，㽷瘦間の抗 体価の比較は必ずしも容易ではない。
4. 薬剂耐性別血清抗体価について

ディスク感受性の 3 濃度法で（一）以下を耐性こした 場合の楽剂耐性別の血清抗体価の検討では, アミノ配糖 体系薬剂耐性以外はすべて同程度で差を認めなかつた。 アミノ配糖体系抗生剂耐性株は全株 S. faecalis で, こ れも先に述べた如くグラム陽性球菌群の問題である。検 討対象の始どの症例は長期留置症例で臨床症状が安定し ており薬剤の投与は最近行なわれていないことが，薬剤 耐性別検討で抗体価の上昇に差を認めなかつた原因であ 万うと思われる。

5. 菌数と血清抗体価について

菌数と抗体価の㛟刺では，著者の成績では，菌数が $10^{4} / \mathrm{ml}$ の抗体洒陽珄率は $0 \%$ で， $10^{5} / \mathrm{ml}$ で $43 \% ， 10^{6} /$ $\mathrm{ml}, 10^{7} / \mathrm{ml}$ で70〜80\%, $10^{8} / \mathrm{ml}$ で $100 \%$ と菌数の増加と 之もに抗体価陽性率の上昇を認めた。 $10^{4} / \mathrm{ml}$ で分離导 れた菌の株数が少ないために断言は出来ないが，抗体佻 からの評価でも， $\mathrm{Kass}^{22)}$ の起炎菌の判定基準の $10^{5} / \mathrm{ml}$ 以上を支持する結果となつた。検討対象の全例がカテー テル留置混合感染例で, 分離菌毎の菌数の算定は繁雑を 極め, $10^{4} / \mathrm{ml}$ で分離されたのは僅か 8 株に過ぎず $10^{3} / \mathrm{ml}$ 以下での分離菌は認められなかつた。河田ら ${ }^{23)}$ の報告に よると，混合感染の in vitro の奏験で, E. coli と S. epidermidis を用いた場合, 両者間に $10^{3} / \mathrm{ml}$ 以上の菌数 のひらきがあると，菌数の少ない側の S. epidermidis の検出が不能であるとしている．著者の検討対象症例の 分離総菌数は多くの場合 $10^{7} / \mathrm{ml}$ 程度であるので, 河田 $ら^{23)}$ の見解に従えば， $10^{4} / \mathrm{ml}$ が分離の限界值であらら かと思われる。堵者の検討例で明らかなように $10^{4} / \mathrm{ml}$ で分離されることは稀で，殆どの分離菌は $10^{5} / \mathrm{ml}$ 以上: で分離され，分離菌の大半が抗体価の上昇を認め慢性腎 监腎炎の病態に深く関与しているものと考无られる.塚 田 ${ }^{24)}$ \& Candida albicans による头験的腎盖腎炎の作 成上，菌量は重要であると報告している。同様に血清抗 体価の上昇と感染菌の菌数との関係は, 山本 ${ }^{7)}$, Carter $ら^{12)}$ もく相関するとしている。 以上より，カテーテル 留置感染症に於ける治療法の原則としては，菌量を可及 的に減少させることであつて，今回の成績では，抗体価 陽性值をとらない $10^{4} / \mathrm{ml}$ 以下に少くとも菌量を㧕える ことであろう．この意味で，腎搵洗浄は有用なものと思 われ，また菌量増加時の一時的化学療法の意義が認めら れるが，根本的には tubeless の状態が望ましいことは䇺 うまでもない。

6. 菌量の推移と血清抗体価について 
菌量の推移が抗体価に 及ぼす影響を検討してみた場 合， 2 週の期間中に菌量の増減とともに抗体価が上下動 する傾向を認めた。勿論, 逆相関の関係で動くものも認 められたが，菌量が 1 order 以上の変化を示す場合は, 抗体価の変動は菌量の増減によく一致した。このこと は，抗体価の持続は抗原に上る慢性刺激が必要であるこ とを表わしているものと思われる。

以上の検討の結果, 抗体価の変動に影響を与える因子 としては菌量の絶対数と变動であることが明らかになつ た.カテーテル留置感染症に於壮る細菌尿は放置されて いるのが現状ではあるが，わるくとも菌量の增減の監視 が必要で, さらに菌株毎に別個に菌数を測定することが 望ましく, 異常增加傾向の認められた時には直ちにとの 菌株注対する化学療法を行ならことが必要であるう。

7. 再生 $\mathrm{ACB}(\mathrm{R} \cdot \mathrm{ACB})$ と血清抗体価淿いて 1974年, Thomas $5^{3)}$ が上部尿路感染巣由来の細菌は, 感染病巣局所で産生される抗体で被覆されて括り蛍光免 疫染色により検出出来ることを報告して以来, antibodycoated bacteria (ACB) についての研究報告が内外で多 数認められるようになつた。現在の処，ACB の意義は 感染部位診断に有用といらことにある。これまでの感染 部位決定法である, glitter cell の検索 ${ }^{25}$ ，尿管カテーテ

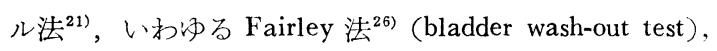
simplified water-loading test ${ }^{27)}$ 等に替る, 簡便で患者に 苦痛を与皇ない方法として評価はかたまりつつある。

細菌に抗体が結合しているということは，その細菌に よつて生体に免疫反応が起こされていることを示し, し たがつてその菌株が生体に刘して病原的意義を有すると いらことを示していることになるＡCB の応用例の 1 つとして, 混合感染症に沶いて複数の分離菌のいずれの 菌株が ACB 陽性なのか判別することであるが，これで それぞれの菌株が感染菌か污染菌かに選別できる可能性 がある、しかし，形態のみによつて菌株の同定は困難で あり，また培養を行ならと被覆抗体は取れてしまら。乙 たがつて少くとも原法によつて混合感染菌を選別するこ とは現在の処手技上不可能であるが，混合感染の実体の 解明溭味がもたれる点でもある ${ }^{28)}$. ACB の研究報告 は多種彩々であるが，1977年 Smith $5^{29}$ の家鬼の実験 的腎盂腎炎に於活るACB の発現の時期と血清抗体，尿 中抗体の発現時期についての検討は興味深い. 彼らの成 績によると，ACB が80\%以上陽性になる時期は腎孟腎 炎作成後11〜12 日目であり 2 週以後は100\%陽性になる としている。また，血清抗体は8日までに上昇を認め尿
中抗体は血清抗体出現に遅れること 3 日，すなわち11日 目に検出可能で15日目以後は $80 \%$ 以上陽性になつたとし ている。すなわち，腎盂腎炎では，血清抗体， $\mathrm{ACB}$ ，尿 中抗体の順で検出可能であり, いずれは 2 週間以内で反 忍の極值に達するといらことである。しかし, 教室の蟹 本ら ${ }^{30}$ によると, 逆行性感染の腎㙉腎炎（家鬼）では感 染後 3 日以内に ACB が検出されている.とにかく今回 の検討で，検体の採取を 2 週每にしたのは患者の通院の 都合であるが，2 週間という interval は免疫反応の time lag を十分に補つたもので理にかなつているものと言え よう。また，ACB がおよそ1週目より検出されはじめ 2 週で100\%検出可能であるという成績の報告は重要で あつて, 種々の尿路疾患で諸家より $\mathrm{ACB}$ 陽性率が報告 されているが，測定時期を明確にしないと一概に論じら れないことになる。この問題に関しては Jones ら ${ }^{31}$ の頻 回培養時の $\mathrm{ACB}$ 検出率の報告があつて, 観察期間中に $\mathrm{ACB}$ 陽性化例抢よび陰性化例を認めたとしている.

今回の著者の検討では, 慢性腎孟腎炎では $\mathrm{ACB}$ は全 例陽性で饬つた。今回の主目的は尿路疾患別の ACB 陽 性率の検討ではなく, 混合感染症に括ける1症例内の 分離菌別 ACB の検討である。ただし，方法としては $\mathrm{ACB}$ に似て非なる $\mathrm{R} ・ \mathrm{ACB}$ にて検討することになつた のであるが，同様の方法は，Smith $5^{29)}$, 湯浅ら ${ }^{32)}$, Kwasnik $5^{33}$ が試みている。さてR・ACB は, ACB の 被覆抗体が specific anibody と仮定して生まれた検出法 であるが，間接的に血清中あるいは尿中抗体の証明法に なると考えて支障ない、この際, treat させる血清およ び尿の濃度は問題があつて, 今回の検討では, 血清は原 血清，尿は25倍濃縮尿を用いた。湯浅ら ${ }^{32}$ によれば， $\mathrm{U}-\mathrm{R} \cdot \mathrm{ACB}$ の場合 10 倍濃縮尿と 20 倍濃縮尿で蛍光の程 度に変りなかつたとしている。しかし， U-R・ACB の 検出が尿中抗体の検出に関係があるとすれば， treat す る尿の濃度は問題であつて今後の検討課題である。ま た， R・ACB 作成にあたつて，血清，尿执よび蛍光標識 抗血清との incubation をスライド上に叙布した検体で操 作して，Thomas ら゙の原法と異なる万法を採用したが， この点については Silverberg ら ${ }^{34) か ゙ す て ゙ ル ~ s l i d e ~ g l a s s ~}$ 上で smear と抗血清を反応させる方法を報告しており， 箸者ら ${ }^{35)}$ も酵素抗体法による ACB の検出を検討しておう り問題はない. 本法は濃縮尿と抗血清は少量で充分で抗 血清の節約になる優れた方法と考えている。

$\mathrm{R} \cdot \mathrm{ACB}$ の抗体別検討で，IgG による S-R・ACB は 血中抗体価と有意の相関を認めたことより， S-R・AC 
は血清抗体の検出法で岕り血清抗体価の定性版的要素を 持つていると考觉られる。また， U-R・ACB と血清抗 体価の間には相関を認めなからたが，慢性腎監腎炎に於 ける血清抗体価と ACB 検出度の相関については, 諸家 の報告が苛る。Thomas ら ${ }^{3)}$ は， Indirect fluorescent 法 にて ACB 陽性例で血清抗体価上昇例が多いことを認め ているし, Pujol ら ${ }^{10)}$ も部尿路感染症で血清抗体価の 上昇と $\mathrm{ACB}$ 陽性化との間に有意の相関をみとめてい

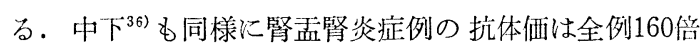
以上を示し，特汇 ACB 陽性例では320倍以上であつた としている，以上より，ACB に直接の類似を思わせる U-R • ACB は IgG の場合, 血清抗体価との関連性から は ACB とかなりの懸隔を認める。しかし，抗体分析で 各免疫グロブリンの $\mathrm{ACB}$ と U-R・ACB の陽性率をみ るとかなり似かよつた成績を示した。上田ら ${ }^{11}$ は IgG は14例全例が陽性で一部に IgM 陽性例を認めたが IgA

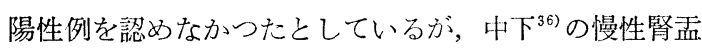
腎炎汇扣ける成績では IgG 100\%，IgM 22.8\%，IgA $33.3 \%$ の陽性率で，U-R・ACB の陽性率は，直接の比 較にならないが IgG $74.1 \%$, IgA 55.0\%, IgM 15.6\% となつて各免疫グロブリンの陽性率の順序は両者同様で 㟧る。

また，血清抗体価が高値のものが必ずしも U-R ・ ACB 陽性ではないといら成績は, 尿中抗体が単なる血中から の漏出ではなく，上部尿路とく腎実質での局所産生が 示唆される．この点に関しては, Aoki ら ${ }^{377}$ はヒトの細 菌性腎盂腎炎の生検標本で間質組織, 尿細管, 尿細管上 皮, macrophage，血管壁に細菌や無定形の細菌抗原を認 め, さらに abacterial pyelonephritis の際にも細菌抗原 を認めている，上田ら ${ }^{11)}$ も慢性腎盂腎炎症例の腎生検材 料で尿細管間質に細菌抗原を認め, リンパ濾胞様細胞浸 潤を認める局所に IgG，IgM の局在を認めたとしてい る。慢性腎孟腎炎の成立は, 腎病巣局所一紏菌抗原の固 着とそれ流く免疫反応の巷起が重要であると考兄られ るが，腎組織内の免投反応と U-R・ACB とが直結して いるものか否かについては疑問が残る.

今回の分離菌別 $\mathrm{R} \cdot \mathrm{ACB}$ の 1 尿路内での検討では, $\mathbf{R} \cdot \mathrm{ACB}$ 陽性となる菌は1菌種だけに限定されるという ことは少く, 分離菌の大半が陽性となつた。この事は, 混合感染で分離された菌の多くが単なる污染菌ではなく 起炎菌として意味をもつものであると言兄よう。

免疫グロブリン別には， IgG が S-R・ACB，U-R • CB で陽性率が最も高いことから，血清，尿中抗体の
主役であり，IgA は補足的に関与し，IgM は少くとも 慢性疗路感染症では関与の度合が少ないと考光られる。 また S-IgA は血中より㽷中での 役割が 重要といらこと

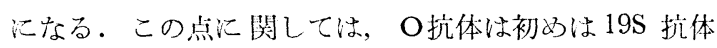
(IgM Class) の及と考光られていたが，Hanson ${ }^{38)}$ 2-mercaptoethanol で処理後に残る $7 \mathrm{~S}$ 抗体 (IgG, IgA class）で抗体洒の測定が可能であつた報告や, Vosti ら ${ }^{399}$ の腎酉腎炎では $7 \mathrm{~S}$ 抗体の上昇が特徵的であるとする報 告以一致している.

8. 尿中免恔グロブリンと U-R・ACB について

カテーテル留置症例の尿中免疫グロブリンは，14例中 正常域任留まる症例は，IgG 2 例 (16\%), IgA 4 例 (28 $\%), \operatorname{IgM} 10$ 例 (71\%), S-IgA 3 例 (21\%) で IgM 除くとすべて高值を示し，正常範囲に留まることが多 いIgM も異常高值を示与症例があることが明らかにな つた。慢性腎而炎の尿中免疫グロブリンについては，中 下 ${ }^{36)}$ もSRID 法で測定して扮り異常高值を示したものは IgG で 3 例 IgA で 1 例であり, IgM は全例 $0.1 \mathrm{mg} / \mathrm{dl}$ 以下としている。著者の検討例でもパルチゲン法であれ ばほぼ中下の 測定值に近いものと思われるが， E.L.I. S.A. 法によつたため $\mu \mathrm{g}$ 単位での比較が可能となつた.

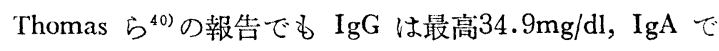
は $15 \mathrm{mg} / \mathrm{dl}$ で，IgM は大半は測定不能であつたとして いるが $0.2 \mathrm{mg} / \mathrm{dl}, 1 \mathrm{mg} / \mathrm{dl}, 41 \mathrm{mg} / \mathrm{dl}$ の高值をとる 3 症例 を報告して招り，IgM でも異常高值を示す症例がある ことは明らっつである。

次に，尿中免疫グロブリンの多寊と U-R ・ ACB の関 係では，IgG と IgA では陽性群と陰性群の間で免疫グ ロブリンの量的差を認めず，IgM と S-IgA で明らかに $\mathrm{U}-\mathrm{R} ・ \mathrm{ACB}$ 陽性群で高値を示した。このことは, IgG と IgA K関しては尿中に non-specific な natural antibody が多く, IgM と S-IgA ではより specific な免疫グロブ リンで占められていること，执よび前者が腎実質内部で 感作を受けるのに対し，後者はこれょりさらに尿路に面 した部位，例えば尿細管あるいは耎酉で感作されるので はないかといら推測がなされる，少くとも免疫の場が異 なる印象がもたれる。また，尿中の分離菌に specific な antibody は感作部位（腎尿細管）で産生され尿中に分泌 され，一方 non-specific antibody (natural antibody) は 炎症反応に伴つて主として腎間質組織を中心に增産さ れ，血清中にも增加しまたこれらの尿中への増加は慢性 㛑㙉腎炎の尿細管障害の結果として血中からの漏出抗体 と考劣ると，血清中濃度の高い IgG と IgA で尿中免疫 
グロブリンに non-specific な抗体が多く，反対に血清濃 度の低い IgM と S-IgA では尿中に natural antibody が少くてょり specific な抗体で占められているという上 記の実験成績が理解される。また， specific antibody の IgG と IgA class の尿中免疫グロブリンは分離菌感作 の結果であると考学られるが，IgM と S-IgA に関して は, U-R ・ ACB 作成の事実から流尿中での免疫反応も 充分考兄られる。

9. 尿中抗体価と U-R ・ ACB そついて

尿路感染症に括活る尿中抗体価については，1966年 Pearsall ら ${ }^{5)}$ が最初に報告していて，原尿の 2 倍以上を 抗体価陽性としている．彼らの成績によると54例中12例 （22\%）が尿中抗体価陽性例で最高でも16倍であつたと している、著者の成績では，濃縮尿を使用したため浸透 圧の関係で測定不能となる case も梕めたがこれを陰性 と考光ると 12 例中 3 例（25\%）が 尿中抗体価陽性で注 涪同様の成績であった。U-R・ACB と尿中抗体価の関 係については，S. faecalis を除く17株中 8 株が抗体価 陽性例で 8 株すべて U-R・ACB 陽性であつた。これ は, S-R ・ ACB が血清抗体価の定性反応であると同様, U-R • ACB が尿中抗体価の 定性試験といら可能性が強 いと考えられる。さらに，1尿路から分離された複数の 菌が血清抗体価，尿中抗体価括よび R・ACB で陽性を 示すことが多いといら実験成績は, 混合感染症の分離菌 汇均等の起炎性を附与するものである。 また，尿中抗体 価と血清抗体価との間に必ずしも相関関係を認めなかつ

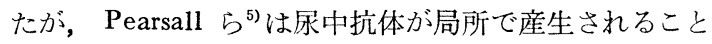
に原因を求めている. また，血清抗体価の感染防禦の意 義としては, Wiliamson ら ${ }^{41}$ は in vivo では antigen が mask され直接の抗体結合が防害され血清抗体は慢性腎 盖腎炎の進行を防止するものではないとしている。同様 化 in vivo で免疫反応を障害するものとしては, Beeson ら ${ }^{42)}$ の腎での ammonia 産生による anticomplimental effect，あるいは Chernew ら ${ }^{43)}$ の尿の高浸透圧による phagocytosis 抑制効果等の報告がある. しかし，著者の 成績では血清抗体価の低い患者の尿に specific antibody を垫めており，Pearsall ら 止し腎盂腎炎の抑制に重要な役割をはたしているのでは ないかと推測している．同様に血清抗体が防禦効果を認 めたとする報告には Kaijser ら ${ }^{44)}$ の家鬼の血行性腎孟腎 炎作成に際し，O6 抗体と K13 抗体の防禦効果を認めた が HI 効体には認めなかつたとする報告もある。また Glynn $ら^{45)}$ のK抗原が phagocytosis 括よび補体の殺菌作
用を防害しているために感染成立を容易にするという報 告からK抗原が注目され，Hanson $5^{38)}$ の rat の上行性 腎盂腎炎の作成でK抗体のほうがO抗体より防禦効果炎 認めるといら報告がある。

また，尿中抗体の origin としては Neil ら $5^{46}$ 打よび Vosti $5^{39)}$ の血清抗体の尿路への漏出説に対し, 局所産 生説として古くは Naylor $5^{47)}$ の urinary typhoid carrier に打ける膀脱での抗体産生, Lehmann $5^{48)}$ の rabbit の 実駼的腎盂腎炎に和ける局所での IgG 産生, Hand $5^{49)}$ の同じく rabbit の実験的膀胱炎での IgG 産生の報告が ある。また臨床例に括いても Uehling $5^{50)}$ の再発性女 子尿路感染症での尿中免疫グロブリン増加の報告等があ るが，著者は先に述べたように両方由来の抗体が存在す るものと推測している.

一方, 呼吸器, 消化器匹打ける分泌型 IgA (S-IgA) が尿中にも認められることを Benenstock ら ${ }^{511}$ が最初に 報告しているが，最近栗山潘は， E.L.I.S.A. 法にて正常 尿路各部に括けるS-IgA の測定の報告をしている。そ 机によると, S-IgA の分泌は, 腎尿管, 膀朕, 尿道と下 部尿路へ行く程分泌量が多いとしている. 著者の U-R . $\mathrm{ACB}$ と免疫グロブリンの検討で S-IgA と IgM がよ? 似た成績を示していて, 共通の免疫反応の場が推測され る・また ACB が腎などの実質性感染の場合にのみ陽性 になることから考兵ると，尿道や膀胧で多量分泌される 自然抗体之異なつて ACB にみられる特異抗体の産生に は局所免疫の場が存在するわけであるが，通常の膀脱炎 では何故局所免疫の場が作られないのか今後解明すべき 問題であらう。

10．尿路混合感染江和许る起炎菌の推定

山本 ${ }^{7)}$ は，尿中分離菌に対する血清抗体の証明は尿路 感染症に括ける起炎菌決定に有用であるとしているが， 著者の成績も同梯であつて，さらに尿中抗体， R・ACB の検討で明確になるものと考光る.今回の検討対象であ る腎典内カテーテル留置症例では，分離菌は複数である ことが多く, カテーテル留置といら特殊条件下で, カテ 一テル付着細菌およびカテーテル交換時の stoma 周四 の付着菌混入は避けられない。このため尿中分離菌のう ち，真の起炎菌と污染茵の鑑別は容易ではない。著者は この点について若干の検討を試みた. 表 3 の如く, 尿中 の分離菌とカテーテル抢よび stoma からの分離菌は必 ナ゙しも一致していないこと，同種の菌種でも strain が異 なると血清抗体価が違うこと， stoma，カテーテルから の分離菌にも血清抗体価陽性の株を認好といら成績を 
表3 大トーマ, カデーテルよりの分離菌と尿分離菌との比較

\begin{tabular}{|c|c|c|c|}
\hline & 永 & ストーマ & カテーテル \\
\hline 右腎 & $\begin{array}{l}\text { E. coli }(4096) \\
\text { P. mirabilis }(64) \\
\text { P. morganii }(64) \\
\text { P. rettgeri }(<8) \\
\text { S. faecalis }(<8)\end{array}$ & $\begin{array}{l}\text { P. mirabilis }(256) \\
\text { S. faecalis }(<8) \\
\text { P. aerug inosa }(128)\end{array}$ & $\begin{array}{l}\text { E.coli (512) } \\
\text { P.mirabilis (64) }\end{array}$ \\
\hline 左腎 & $\begin{array}{l}\text { E. coli }(4096) \\
\text { P. mirabilis }(64) \\
\text { S. faecalis }(<8) \\
\text { NF-GNR }(<8)\end{array}$ & $\begin{array}{l}\text { E. coli }(64) \\
\text { P.mirabilis }(128) \\
\text { S. faecalis }(<8) \\
\text { P. aeruginosa }(128)\end{array}$ & $\begin{array}{l}\text { P. mirabilis }(64) \\
\text { S. faecalis }(<8)\end{array}$ \\
\hline
\end{tabular}

（）：血清抗体価

尿分離菌との一致率

\begin{tabular}{c|c|c}
\hline & ストーマ & カテーテル \\
\hline 右腎 & $1 / 3=33 \%$ & $1 / 3=33 \%$ \\
\hline 左腎 & $2 / 4=50 \%$ & $2 / 2=100 \%$ \\
\hline
\end{tabular}

得た。血清抗体価から考える之，本症例の真の起炎菌は E. coli であつて，その他の菌は污染菌であると考えら れる. stoma，カテーテルからの分離菌で抗体価陽性菌 を認めるが，これは以前に尿中に存在した起炎菌と考兄 られる. カテーテル留置症例においては，カテーテル交 換毎に㾞孔内外の菌が入れ替りを繰り返えし，複雑な様 相を呈する混合感染症になつているものと言えよう。中 下 $^{36)}$ もこの点に関して，尿中から $10^{5} / \mathrm{ml}$ 以上で分離さ れた菌で ACB ぶ゙1/4の症例で陰性であつたとしている. また，本症例ではたまたま E. coli といら一菌種のみが 抗体価陽性を示しているが，一般的には複数の菌が抗体 洒陽性になることが多いのは既述の如くである.

これまでの検討で，混合感染例に打ける起炎性の決定 は，血清抗体価と U-R・ACB の検索が最も重要であろ らかと思われる。血清抗体価と U-R ・ ACB との違いは 局所免疫反応の場の相違によるものと思われるが, 逆行 性感染では一般に U-R・ACB の場よりより深部の実質 へとその場が波及して血清抗体を産生するようになり， さらには菌血症を起こすことによつて血清抗体の著明な 上昇が䞏められるものと思われる。 S-R ・ ACB の IgG は浪ぼ血清抗体価で代用出来るし，その他の免疫グロブ リンによる S-R・ACB は意味が不明である。また，尿 中抗体価は U-R A ACB と同様局所免疫反応をみる点で 意義深いが，現在の hemagglutination 法では測定不能 例も生じることと，IgG の U-R ・ACB で注湆代用出来 ること，扎び IgM, S-IgA の U-R・ACB はその他の 尿中局所免疫反応を㕕られる点で U-R ・ ACB の検出を
推挙したい、しかし尿中細菌の菌数を個別に测定するこ とによつてもある程度の選別は可能である。

\section{結語}

カテーテル留置混合感染症例で，泉中分離菌の個別菌 数，血清抗体価，尿中抗体価， $\mathrm{R} \cdot \mathrm{ACB}$ の検出，拉よひ 尿中免疫グロブリンの測定を行ない以下の結果を得た。

1. 患者の自己糞便分離菌の血清抗体価の測定から, 抗体価陽性限界值を128倍以上とした。S. faecalis や NF-GNR を除くと分離菌別および楽剤耐性別には血清抗 体価の差を認めなかつた・カテーテル留置部位別には， 上部尿路, 㽷道, 下部尿路留置の順に血清抗体価は嵪値 文示した。

2.一尿路より分離された複数分離菌の血清抗体価 は，菌数に比例して高值となる傾向を認めた２２週間の 間隔を置く 2 時点の抗体価の変動も菌量の増減に比較的 よく同調する傾向を認めた。

3. R・ACB の検傠で， IgG の S-R ・ ACB \&血清抗 体価と，U-R・ACB は尿中抗体価と相関する傾向を認 めた。抗体分析の結果は，S-R・ACBでは IgG，IgA で 陽性率が高く，U-R・ACB では IgG，S-IgA で陽性率が 高かつた。慢性腎需腎炎では，IgM の関与は少ないと 思われた。

4. 尿中免度グロブリンを E.L.I.S.A. 法で測定し U-R・ACB との相関を検討した，カテーテル留置症例 の各種免疫グロブリンはいずれも高值を示したＵ-R ・ $\mathrm{ACB}$ 陽性の尿中免疫グロブリンは S-IgA で高值を示 し，陽性率は低いかＩgMでも高值を示した。IgG，IgA 
では尿中免疫グロブリン量と U-R・ACB 陽性間に相関 を認めなかつた。

5. 疗中抗体陽性率 は 12 症例中 3 例 (25\%) であつ た。尿中抗体価陽性株は全例 IgG の U-R ・ ACB は陽 性であつた。一尿路の分離菌のらち複数の分離菌が，血 清抗体価，尿中抗体価， R ・ ACB 陽性であつた.

6. 血清抗体価，尿中抗体価， R ・ ACB は分離菌の起 炎性決定に有用な検查であることが示唆された。

7. 慢性の混合感染症で分離される菌のうち, 少くと も尿の通常の培養法で検出される菌株についてい污染菌 の占める割合は少なく, 分離菌の殆どが起炎菌と考学る べきで，生体側への侵襲の程度としてみた血清抗体価に 菌量が与える影響には重大なものがあつた。したがつて 臨床上可及的に菌量の減少をはかるべきものと考兄られ た。な敃疫反応がある程度菌数に比例した事実より， 混合感染では菌株別に菌数を測定して観察することが必 要であると考えられた。

本論文の要旨は第26回日本化学療法学会西日本支部総 会および第67回日本泌尿器科学会総会で発表した。

稿を終るに臨み，終始愁切なる御指導と御校閲を賜っ た恩師西浦常雄教授と河田幸道助教授に深甚の謝意を表 わすと共に，種々の御協力をいたたいた医局員諸兄に感 謝いたします。.

\section{文献}

1)河田幸道, 西浦常雄 : 尿路感染症における化学 療法剤の薬効評価基準についてII. 複雑性尿路 感染症における薬効評価基準。日泌尿会誌, 70, $534-545,1979$.

2) Kunin, C.H.: Antibody distribution against non enteropathic E. coli. Arch. Intern. Med., 110, 676-686, 1962.

3) Thomas, V., Shelokov, A. and Forland, M.: Antibody-coated bacteria in the urine and the site of uninary tract infection. New Engl. J. Med., 290, 588-590, 1974.

4) 栗山学: E.L.I.S.A. 法による尿中兔疫グロブ リンの測定。日泌尿会誌，70，228-233，6 6 [79.

5) Pearsall, N.N. and Sherris, J.C.: The demonstration of specific urinary antibodies in urinary tract infections caused by gram-negative bacilli. J. Path. Bact., 91, 589-595, 1966.

6) Neter, E., Bertram, L.F., Zak, D.A., Murdock, M.R. and Arbesman, C.E.: Studies on hemagglutination and hemolysis by Escherichia coli antisera.: J. Exp. Med., 96, 1-15. 1952.

7) 山本隆司：尿路感染症の免疫学的研究。第 1 編
正常人血清及び急性膀胱炎患者血清抗体（赤 血球凝集素価）。日泌尿会誌，55，386-395， 1964.

8) Needell, M.H., Neter, E., Staubitz, W.J. and Bingham, W.A.: The antibody (Hemagglutinin) response of patients with infections of the urinary tract. J. Urol., 74, 674-672, 1955.

9) Percival, A., Brumfitt, W. and Louvois, J.: Serum-antibody levels as an indication of clinically inapparent pyelonephritis. Lancet. II, 1072-1033, 1964.

10) Pujol, A., Linares, F., Munoz, J., Rusconi, A., Orejas, V.: A new method for detection and localization of urinary infection: The fluorescence antibody test. Eur. Urol., 2, 145-148, 1976.

11）上田泰, 大森雅久, 井原裕宜: 腎疾患の免疫 組織学的アプローチ 4. 腎孟腎炎と免疫. 日腎 誌, 19, 835-839, 1977.

12) Carter, M. J. and Ehrenkranz, N.J.: Immunologic studies in urinary tract infections. Correlation of hemagglutinin response with bacteriuria following catheterization. J. Lab. Clin. Med., 67, 13-22, 1966.

13) Scarpelli, P.T., Bigioli, F., Masini, G., Majo, E. De. and Romeo, B.: The antibody response in chronic pyelonephritis. Clin. Nephrol., 12, $7-13,1979$.

14) Lancefield, R.C.: A serological differentiation of human and other groups of hemolytic streptococci. J. Exp. Med., 57, 571-595, 1933.

15) 津田恭介, 野上 寿: 微生物薬品化学, 医学薬 品開発基礎講座 IV, p. 35-41, 地人書館, 東 京, 1971.

16) Hewstone, A.S. and Whitaker, J.: The correlation of ureteric urine bacteriolcgy and homologous antibody titer in children with urinary infection. J. Pediatr., 74, 540-543, 1969.

17) Ehrenkranz, N.J. and Carter, M.J.: Immunologic stadies in urinary tract infections. J. Immun., 92, 798-805, 1964.

18) Clark, H., Ronald, A.R. and Turck, M. et al. : Antibody response in renal versus bladder bacteriuria. J. Infect. Dis., 123, 539-543, 1971.

19) Jones, S.R.: Prostatitis as caused antibodycoated bacteria in urine. New Engl. J. Med., 291, 365, 1974.

20) Thorley, J.D., Barbin, G.K. and Reinarz, J.: The prevalence of antibody-coated bacteria in urine. Amer. Med. Sci., 275, 75, 1978.

21) Stamey, T.A., Govan, D.E. and Palmer, J.M.: The localization and treatment of urinary tract infections. The role of bactericidal urine 
level as opposed to serum level. Medicine. 44, $1-36,1965$.

22) Kass, E.H.: Bacteriuria and the diagnosis of infections of urinary tract. Arch. Int. Med., 100, 709-714, 1975.

23) 河田萃道, 西浦常雄: 尿路感染症に打方菌交 代. 最新医学, 34, 1759-1768, 1979.

24) 塚田修, 岸洋一, 新島端夫, 山口英世 : Candia albicans による実験的腎孟腎炎の作 成. 第67回日本泌尿器科学会総会 (演), 東京, 1979.

25) Poirier, K.P. and Jakson, G.G.: Characteristics of leukocytes in the urine sediment in pyelonephritis. Amer. J. Med.. 23, 579-543, 1975.

26) Fairley, K.F., Bond, A.G., Brown, R.B. and Habersberger, P.: Simple test to determine the site of urinary tract infection. Lancet, 2, 427-428, 1967.

27) Dontas, A.S., Marketos, P.C., Papanayiotou, P.C., Tsekos, G.N. and Malamos, B.K.: Simplified water-loading test in bacteriura. Nephorn, 12, 121-128, 1974.

28）河田幸道：腎孟腎炎。診断と治療, 65, 4447, 1977.

29) Smith, J.W., Jones, S.R. and Kaijser, B.: Significance of antibody-coated bacteria in urinary seciment in experimental pyelonephritis. J. Infect. Dis., 135, 577-581, 1977.

30)蟹本雄右, 堀江正宣, 栗山学, 出口隆, 河 田幸道，西浦常雍：家鬼を用いた上行性実験的 腎責腎炎（第 II 報），第68回 日本泌尿器科学会 総会（演），神戸，1980.

31) Jones, S.R. and Johnson, J.: Further evaluation of the test for detection of antibodycoated bacteria in urinary sediment. J. Clin. Microbiol., 5, 510-513, 1977.

32) 湯浅正明, 上間健造, 藤村宣夫, 黑川一男: 複 雑性腎血腎炎におけるAntibody coated bacteria の意義。第26回日本化学療法学会西日本支部総 会 (演), 名古屋, 1978 .

33) Kwasnik, I., Klauber, G. and Tilton, R.C.: Clinical and laboratory evaluation of the antibody-coated bacteriatest in children. J. Urol., 121, 658-661, 1979.

34) Silverberg, D.S., Jackson, F.L. and Bryan, L.E.: Antibody coated bacteria in the urine of preschool and school-aged girls with asymptomatic bacteriuria. CMA Journal, 115, 1091 1093, 1976.

35）泟山学, 堀江正宣, 蟹本雄右, 河田幸道, 西 浦常雄: 酵素抗体法による Antibody coated bacteria の検出. 臨床免疫, 10,887-892,1978.

36) 中下英之助: 上部尿路感染症の免疫学的研究. 日泌尿会誌, 69, 1219-1229，1978.
37) Aoki, S., Imamura, S., Aoki, M. and McCabe, W.R.: "Abacterial" and bacterial pyelonephritis. Immunofluorescent localization of bacterial antigen. New Engl. J. Med., 281, 1375-1382, 1969.

38) Hanson, L.A. and Winberg, J.: Demonstration of antibodies of different immunoglobulin types to the O-antigen of the infecting E. coli strain in infants and children with pyelonephritis. Nature, 212, 1495-1496, 1966.

39) Vosti, K. and Remington, J.S.: Host-parasite interaction in patients with infections due to Escherichia coli. III. Physicochemical characterization of specific antibodies in serum and urine. J. Lab. Clin. Med., 72, 71-83, 1968.

40) Thomas, V.L., Forland, M. and Shelokov, A.: Immunoglobulin levels and antibody-coated bacteria in urines from patients with urinary tract infections. Proc. Soc. Exp. Biol. Med., 148, 1198-1201, 1975.

41) Williamson, J., Brainerd, H., Scaparone, M. and Chueh, S.P.: Antibacterial antibodies in coliform urinary tract infection. Arch. Intern. Med., 114, 222-231, 1964.

42) Beeson, P.B. and Rowley, D.: The anticomplimental effect of kidney tissue. J. Exp. Med., 110, 685-697, 1959.

43) Chernew, I. and Braude, A.I.: Depression of phagocytosis by solutes in concentrations found in the kidney and urine. J. Clin. Invest., 41, 1945-1953, 1962.

44) Kaijser, B. and Olling, S.: Experimental hematogenous pyelonephritis due to Esherichia coli in rabbits: The antibody response and its protective capacity. J. Infect. Dis., 128, 41-49, 1973.

45) Glynn, A.A. and Brumfitt, W. and Howard, C.J.: $\mathrm{O}$ antigen of Esherichia coli and renal involvement in urinary-tract infections. Lancet, i, 514-516, 1971 .

46) Neill, J.M., Baspari, E.L. and Mosley, R.A.: Loss of immune substances from the body. J. Immunol., 20, 347-369. 1931.

47) Naylor, R.G.E. and Galdwell, R.A.: The Origin of urinary antibodies. J. Hyg. (Camb.), 51, 245-257, 1953.

48) Lehmann, J.D., Smith, J.W., Miller, T.E., Barneff, J.A. and Sanford, J.P.: Local immune respcnse in experimental pyelonephritis. J. Clin. Invest., 47, 2451-24551, 1968.

49) Hand, W.L., Smith, J.W., Miller, T.E., Barneff, J.A. and Sanford, J.P.: Immunoglobulin systhesis in lower urinary tract infection. J. Lab. Clin. Med., 75, 19 -29, 1970. 
50) Uehling, D.T.: Immunoglobulin excretion in women with recurrent urinary tract infection. J. Urol., 109, 302-303, 1973.

51) Bienenstock, J. and Tomasi, T.B. Jr.: Secretary $\gamma-A$ in normal urine. J. Clin. Invest.,
47, $1162-1172,1968$.

52) 栗山学：尿中分泌型 IgA の研究 (1) 尿路に お汁る局在性について。 日泌尿会誌, 70, 1129-1141, 1979.

（1980年10月 20 日受付） 